\title{
A Silicon Industry Waste Polymethylhydrosiloxane-mediated Benzotriazole Ring Cleavage (BtRC): A Practical and Green Synthesis of diverse Benzothiazoles
}

Mangal S. Yadav, ${ }^{1}$ Anoop S. Singh,${ }^{1}$ Anand K. Agrahari, ${ }^{1}$ Nidhi Mishra, ${ }^{1}$ Vinod K. Tiwari ${ }^{1}$ *

${ }^{1}$ Department of Chemistry, Institute of Science, Banaras Hindu University, Varanasi, UP-221005, India.

*E-mail: tiwari_chem@yahoo.co.in, vinod.tiwari@bhu.ac.in

\section{Contents}

1 General experimental procedure for the synthesis of benzotriazole S2-S5 methanethione derivatives (1a-t).

$2 \quad{ }^{1} \mathrm{H}$ and ${ }^{13} \mathrm{C}$ NMR spectra of benzothiazoles (2a-t) 
1. General experimental procedure for the synthesis of benzotriazole methanethione derivatives (1a-t):

$$
\mathrm{R}-\mathrm{SH}+\mathrm{Bt}_{\mathrm{Bt}} \frac{\mathrm{Py}, \mathrm{CH}_{2} \mathrm{Cl}_{2}}{30-60 \mathrm{~min}} \longrightarrow \underset{\begin{array}{c}
\text { S-Alkyl/Aryl(benzotriazole) } \\
\text { dithiocarbamate (1a-c) }
\end{array}}{\mathrm{S}}
$$

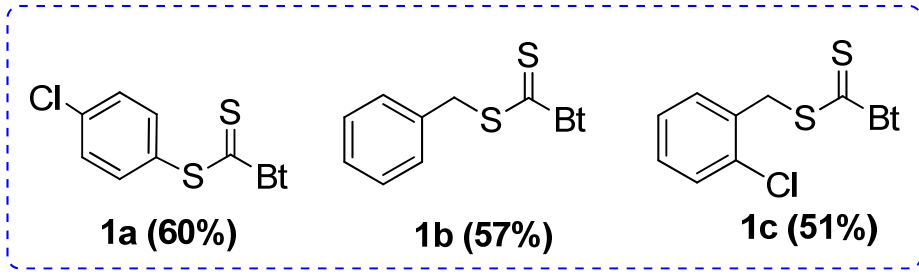

$$
\underset{\mathrm{R}}{\mathrm{R}^{2}} \stackrel{\mathrm{Rt}}{\mathrm{R}}+\underset{\mathrm{Bt}}{10-15 \mathrm{~min}, \mathrm{RT}}
$$<smiles>S=C(Br)N1CCCCC1</smiles><smiles>CCCCN(CCCC)C(=S)Br</smiles>

$1 \mathrm{~g}(85 \%)$

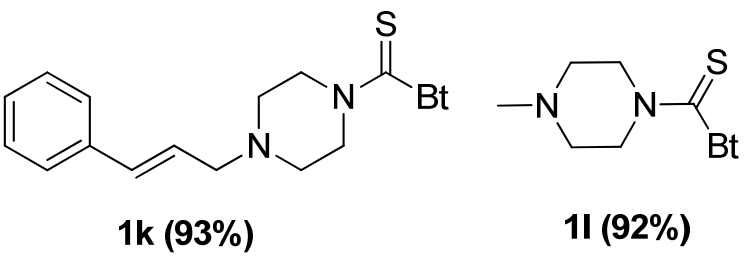<smiles>S=C(CBr)N1CCN(c2ccccc2)CC1</smiles><smiles>S=C(Br)N1CCN(c2ccccn2)CC1</smiles>
1f (94\%)<smiles>S=C(CBr)N(Cc1ccccc1)Cc1ccccc1</smiles>

1h $(57 \%)$<smiles>S=C(Br)N1CCOCC1</smiles>

$1 \mathrm{i}(92 \%)$<smiles>S=C(Br)N1CCN(c2ccccc2Cl)CC1</smiles>
$1 \mathrm{~m}(89 \%)$ 

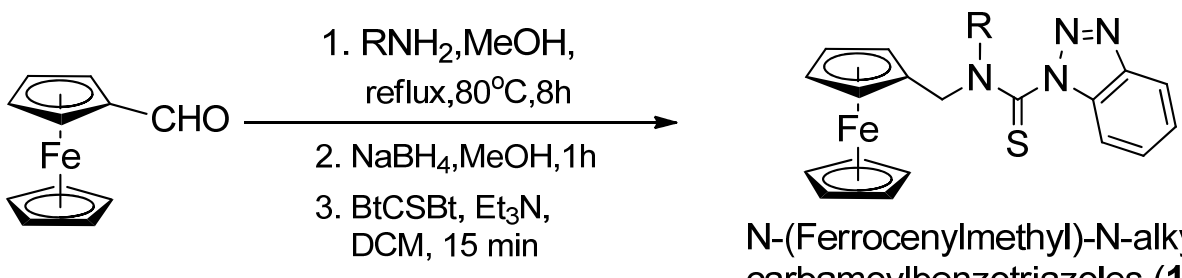

$\mathrm{N}$-(Ferrocenylmethyl)-N-alkylthio carbamoylbenzotriazoles (1n-q)
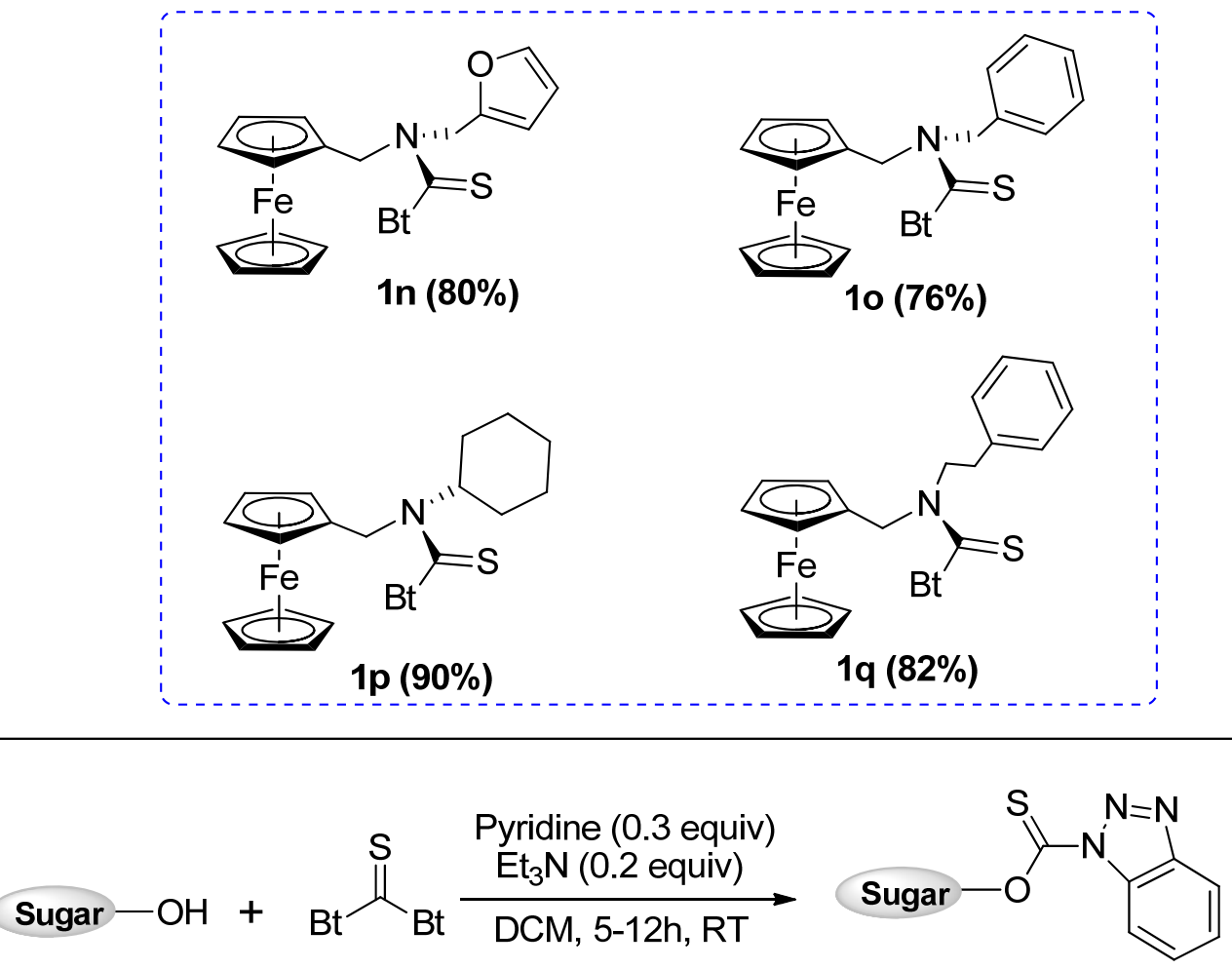

Glycosyl benzotriazole methanethiones (1r-t)

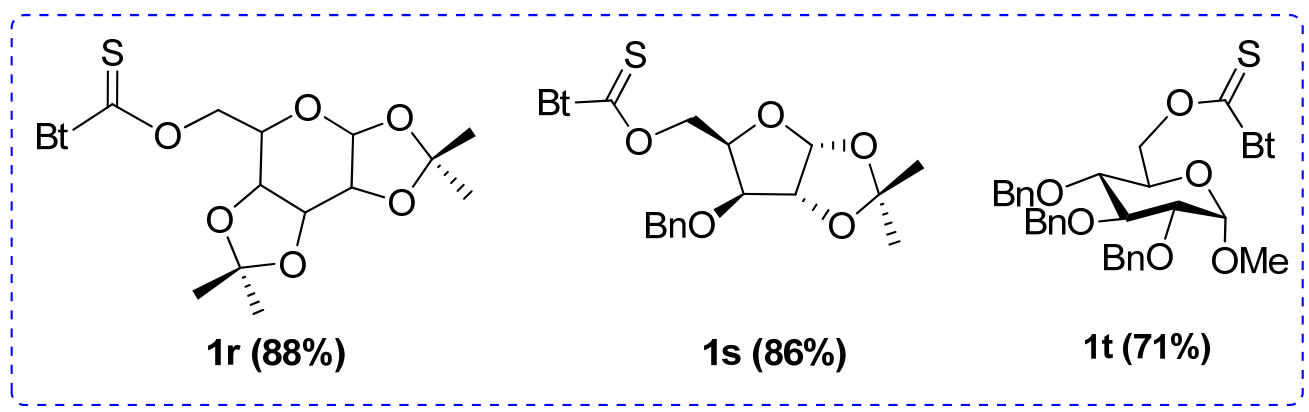

Scheme S1: Representative synthetic protocol of S-aryl/alkylthiothioacylbenzotriazole (1a-c), thiocarbamoyl benzotriazoles (1d-m), $N$-(ferrocenylmethyl)- $N$-alkylthiocarbamoylbenzotriazoles (1nq) and glycosyl benzotriazole methanethiones (1r-t) 


\section{Synthesis of S-aryl/alkylthiothioacylbenzotriazole derivatives (1a-c):}

To a stirring solution of bis(benzotriazolyl)methanethione (1.0 equiv) in anhydrous dichloromethane ( $5 \mathrm{~mL}$ ), mercaptons (1.0 equiv) was added followed by addition of pyridine (as base, (0.2 equiv) and the reaction was continued at $0^{\circ} \mathrm{C}$ under inert atmosphere for 30-60 minutes. After completion of reaction (monitored by TLC), the reaction mixture was dried under reduced pressure and was extracted, washed twice with $10 \% \mathrm{Na}_{2} \mathrm{CO}_{3}$, saturated brine solution, and water followed by drying over anhydrous $\mathrm{Na}_{2} \mathrm{SO}_{4}$. The organic layer was in vacuo concentrated and crude mass thus obtained was subjected to purification by the column chromatography $\left(\mathrm{SiO}_{2}\right)$ using gradient mixtures of ethyl acetate and $n$-hexane and afforded aryl/alkylthiothioacylbenzotriazole scaffolds (1a-c) in pure form. ${ }^{1}$

\section{Synthesis of thiocarbamoyl benzotriazoles derivatives $(1 \mathrm{~d}-\mathrm{m})$ :}

To a stirring solution of bis(benzotriazole methanethiones) (1.01 equiv) in anhydrous $\mathrm{CH}_{2} \mathrm{Cl}_{2}(5 \mathrm{~mL}$ ), secondary amine (1.0 equiv.) was added followed by addition of $\operatorname{Et}_{3} N$ (0.2 equiv) and the reaction was continued for 10-15 min under inert atmosphere at room temperature. After completion of reaction (monitored by TLC), the reaction mixture was washed with $10 \% \mathrm{Na}_{2} \mathrm{CO}_{3}$ (twice), saturated brine solution, and water followed by drying over anhydrous $\mathrm{Na}_{2} \mathrm{SO}_{4}$. The organic layer was in vacuo concentrated and subjected to purification by column chromatography $\left(\mathrm{SiO}_{2}\right)$ using a gradient mixtures of ethyl acetate and $n$-hexane to afford thiocarbamoyl benzotriazole (1d-m) in pure form. ${ }^{1}$

\section{Synthesis of $N$-(Ferrocenylmethyl)- $N$-alkylthiocarbamoylbenzotriazoles (1n-q):}

The synthesis of $N$-(ferrocenylmethyl)- $N$-alkylthiocarbamoyl benzotriazoles which could be used as a synthetic precursor for $N$-alkyl- $N$-(ferrocenylmethyl)benzothiazol-2-amine was obtained from ferrocene aldehyde in three high yielding steps. First of all secondary amines containing ferrocene was 
synthesized using standard reported literature from the readily available ferrocene carboxaldehyde and various primary amines. ${ }^{2}$

A reaction solution of bis(benzotriazole methanethiones) (1.01 equiv) with ferrocene containing secondary amines (1.0 equiv) in presence of $\mathrm{Et}_{3} \mathrm{~N}$ as base in anhydrous $\mathrm{CH}_{2} \mathrm{Cl}_{2}(5.0 \mathrm{~mL})$ was stirred at room temperature under inert atmosphere. After completion of reaction (monitored by TLC), the reaction mixture was concentrated under reduced pressure. The resulted residue was diluted with dichloromethane and washed twice with $10 \% \mathrm{Na}_{2} \mathrm{CO}_{3}$, saturated brine solution and then water. Organic layer was dried over anhydrous $\mathrm{Na}_{2} \mathrm{SO}_{4}$. The organic layer was concentrated in vacuo and purification by the column chromatography using gradient mixtures of ethyl acetate and $n$-hexane afforded $N$ (ferrocenylmethyl)- $N$-alkylthiocarbamoylbenzotriazoles (1n-q) in pure form.

\section{Synthesis of carbohydrate-based benzotriazole methanethione derivatives (1r-t):}

A reaction mixture of orthogonal protected glycosyl alcohol (1.0 equiv) with bis(benzotriazolyl) methanethiones (1.0 equiv) in presence of pyridine ( 0.3 equiv) and triethylamine ( 0.2 equiv) in anhydrous $\mathrm{CH}_{2} \mathrm{Cl}_{2}$ was stirred at room temperature for 5-12 hours under argon atmosphere. After completion of reaction (monitored by TLC), the reaction mixture was dried under reduced pressure and extracted with dichloromethane, then washed with $10 \% \mathrm{Na}_{2} \mathrm{CO}_{3}$ (twice), freshly prepared brine solution and finally with water. Organic layer was dried over anhydrous $\mathrm{Na}_{2} \mathrm{SO}_{4}$ in vacuo concentrated to give crude mass which was subjected to purification by column chromatography $\left(\mathrm{SiO}_{2}\right)$ using a gradient of ethyl acetate and $n$-hexane as eluent and afforded the respective carbohydrate-based benzotriazole methanethione derivatives (1r-t) in pure form. ${ }^{3}$ 
2. ${ }^{1} \mathrm{H}$ and ${ }^{13} \mathrm{C}$ NMR Spectra of benzothiazoles (2a-t)

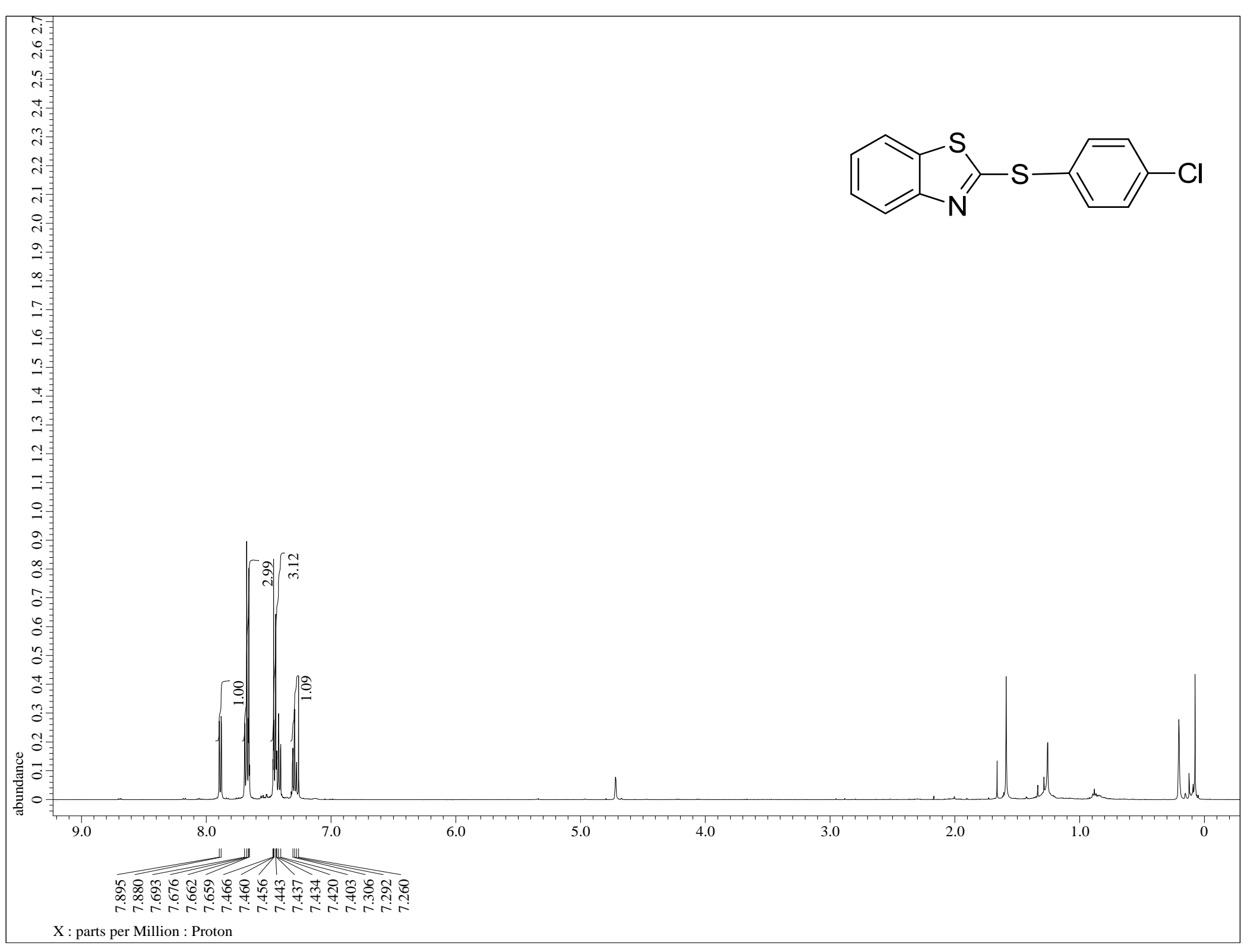

Figure S1: ${ }^{1} \mathrm{H}$ NMR (500 MHz, $\mathrm{CDCl}_{3}$ ) of compound 2a 


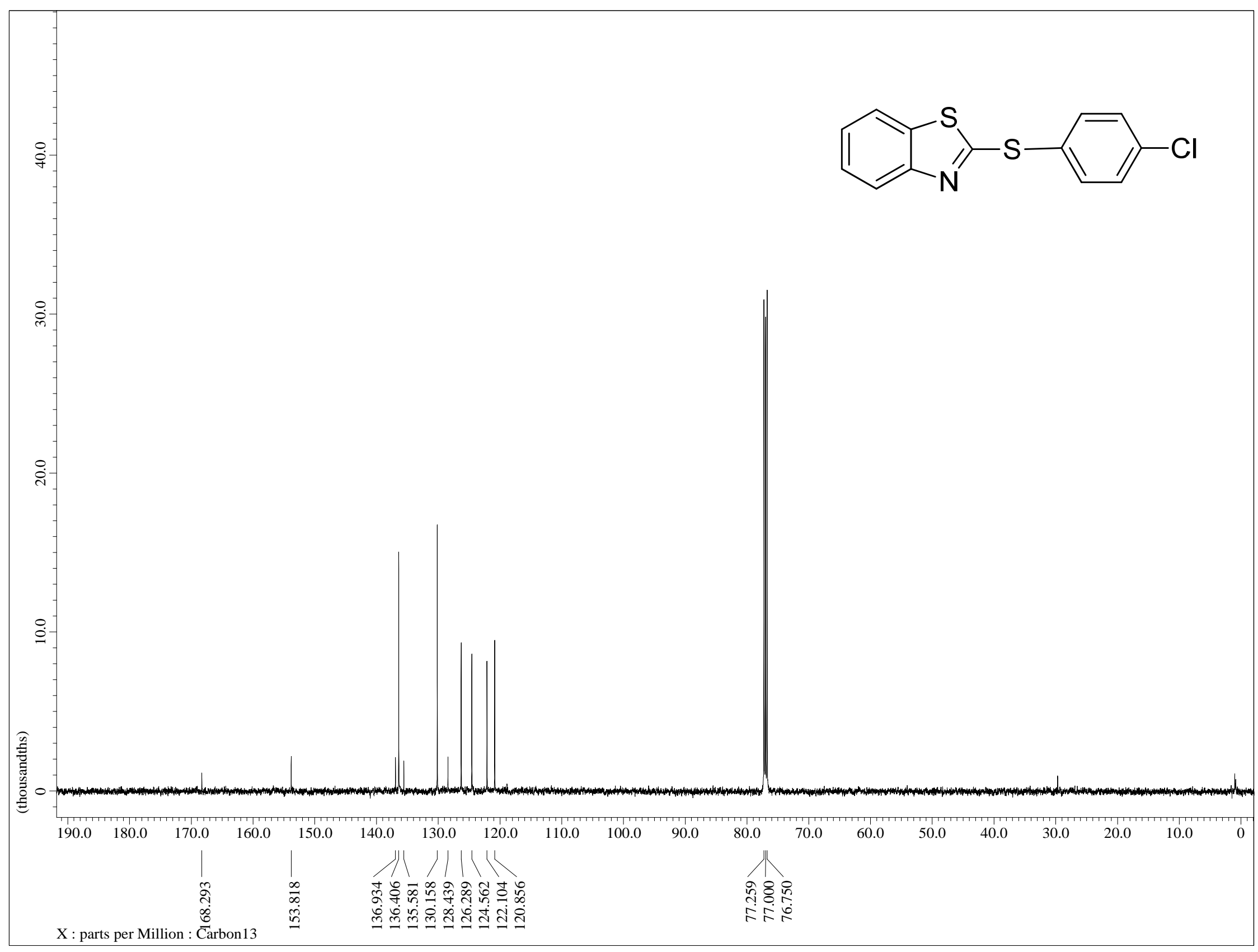

Figure S2: ${ }^{13} \mathrm{C}$ NMR (125 MHz, $\mathrm{CDCl}_{3}$ ) of compound 2a 


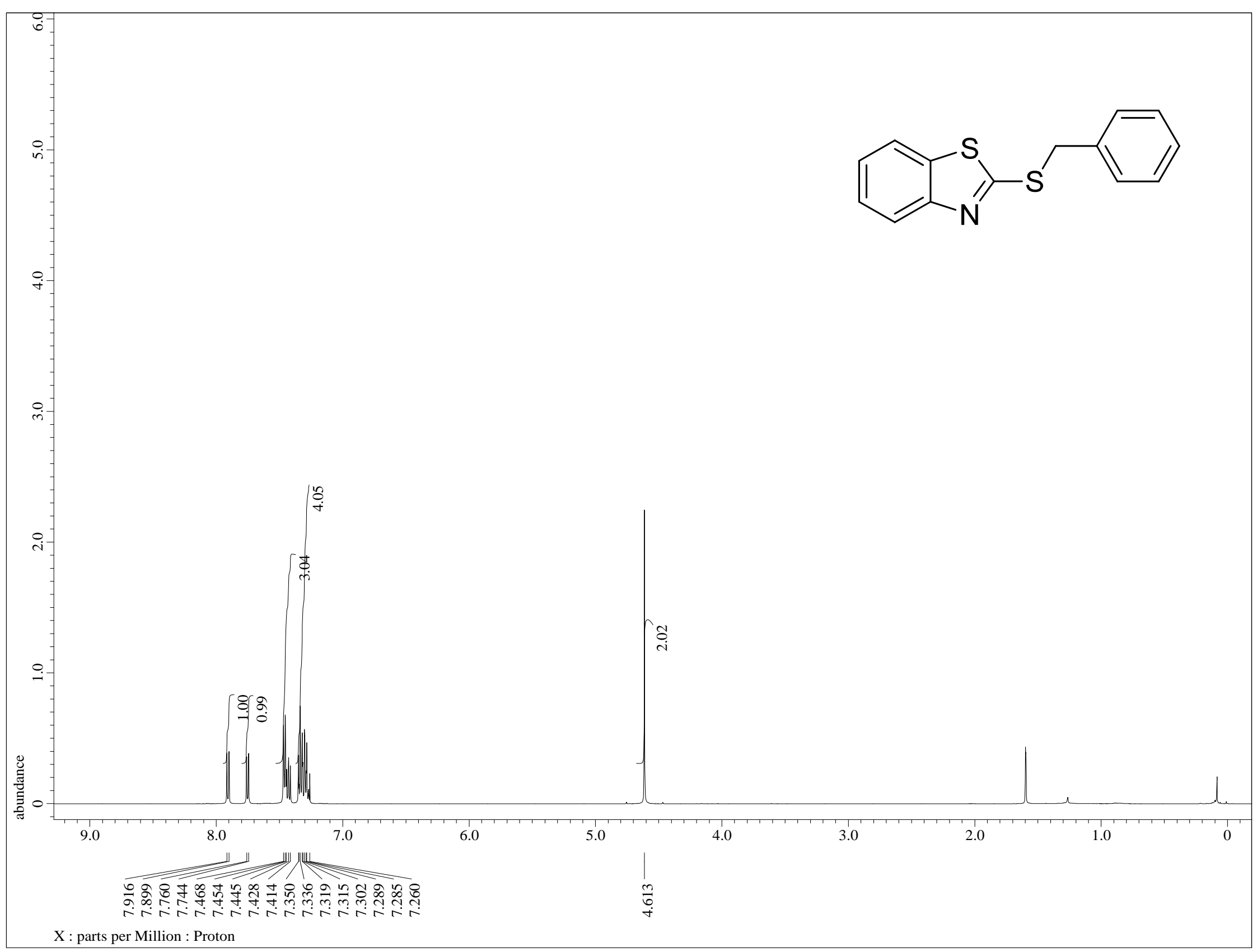

Figure S3: ${ }^{1} \mathrm{H}$ NMR $\left(500 \mathrm{MHz}, \mathrm{CDCl}_{3}\right)$ of compound $\mathbf{2 b}$ 


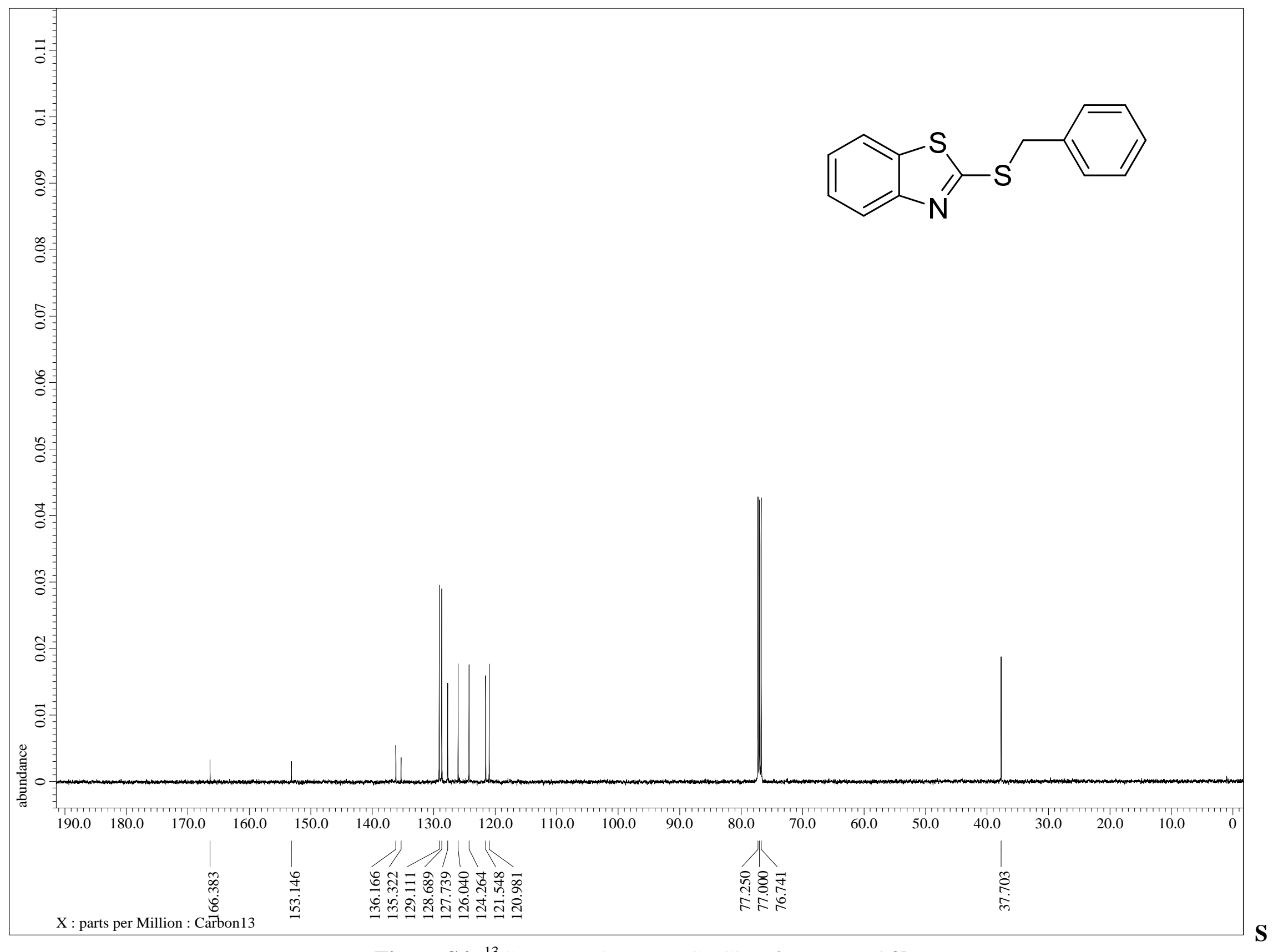

Figure S4: ${ }^{13} \mathrm{C}$ NMR $\left(125 \mathrm{MHz}, \mathrm{CDCl}_{3}\right.$ ) of compound $\mathbf{2 b}$ 


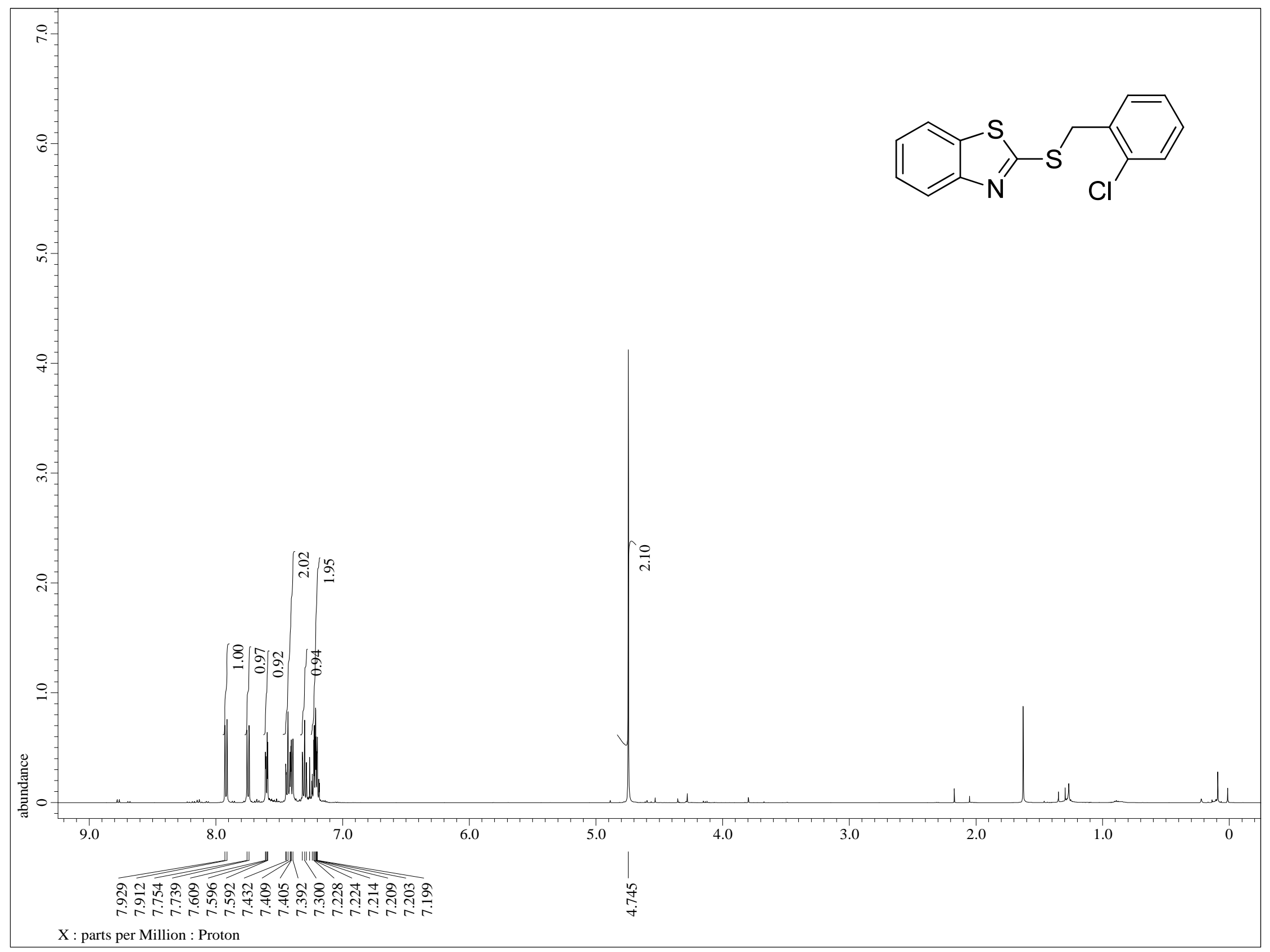

Figure S5: ${ }^{1} \mathrm{H}$ NMR $\left(500 \mathrm{MHz}, \mathrm{CDCl}_{3}\right.$ ) of compound 2c 


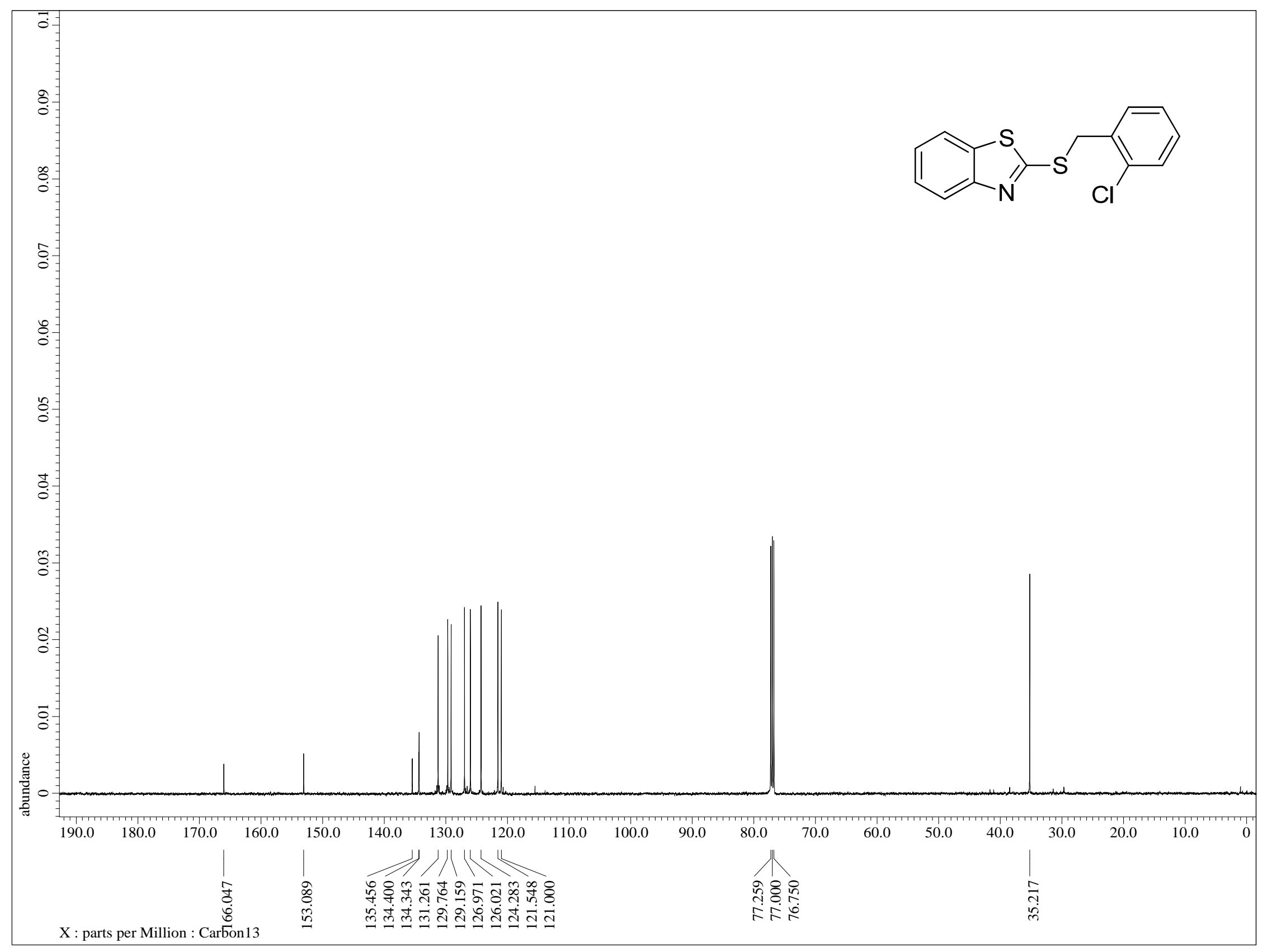

Figure S6: ${ }^{13} \mathrm{C}$ NMR $\left(125 \mathrm{MHz}, \mathrm{CDCl}_{3}\right)$ of compound 2c 


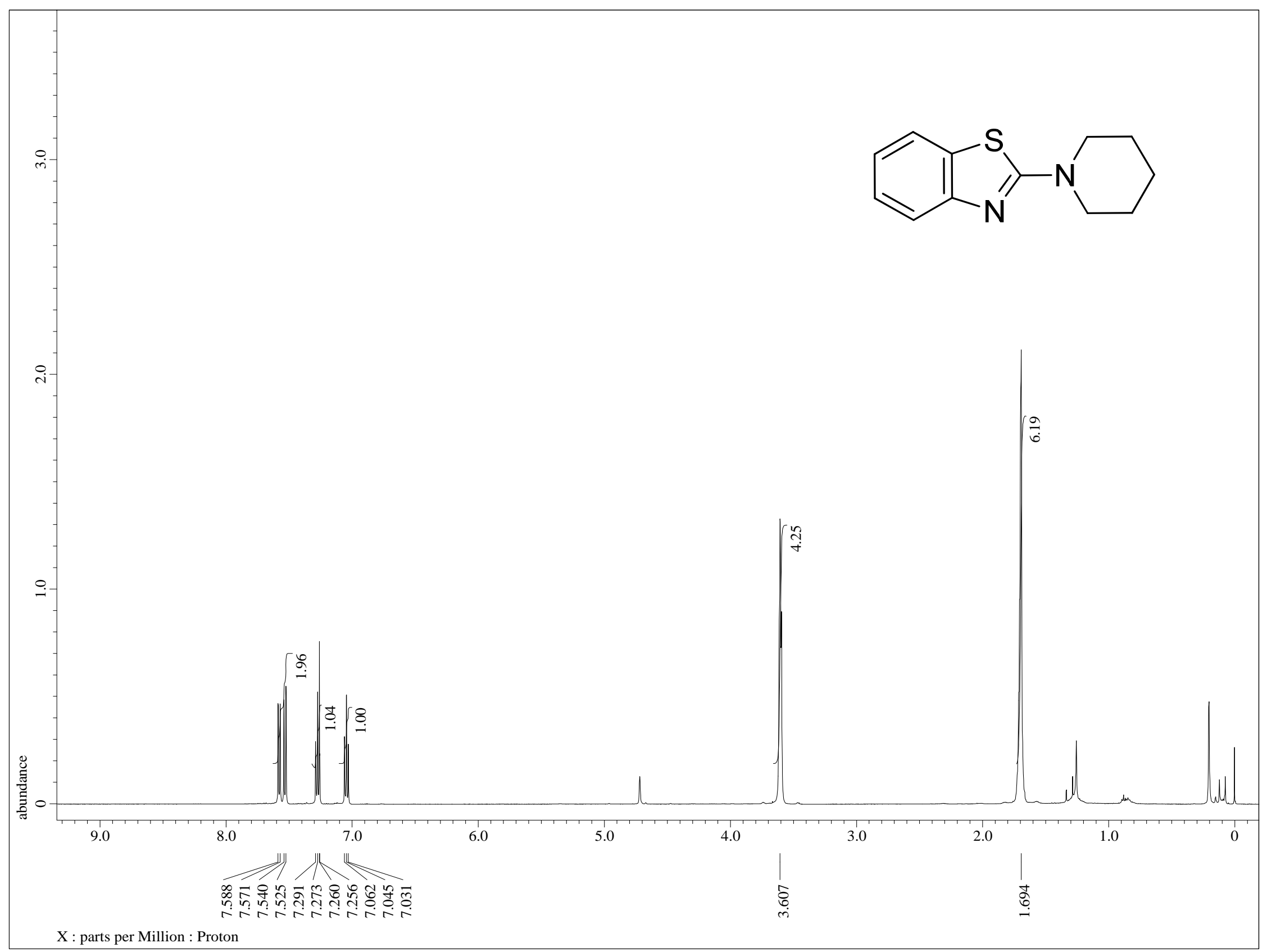

Figure S7: ${ }^{1} \mathrm{H}$ NMR (500 MHz, $\mathrm{CDCl}_{3}$ ) of compound 2d 


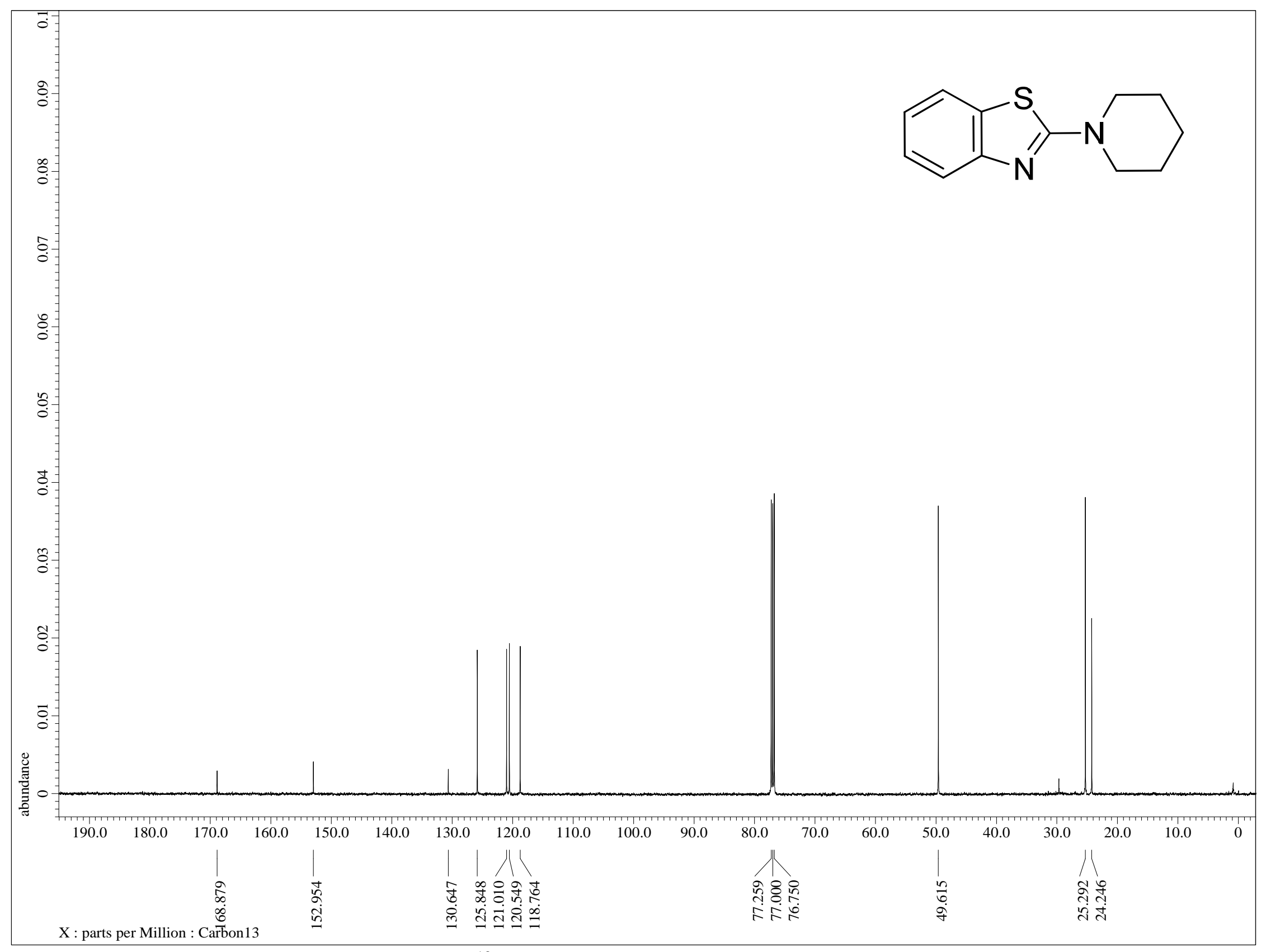

Figure S8: ${ }^{13} \mathrm{C}$ NMR (125 MHz, $\mathrm{CDCl}_{3}$ ) of compound 2d 


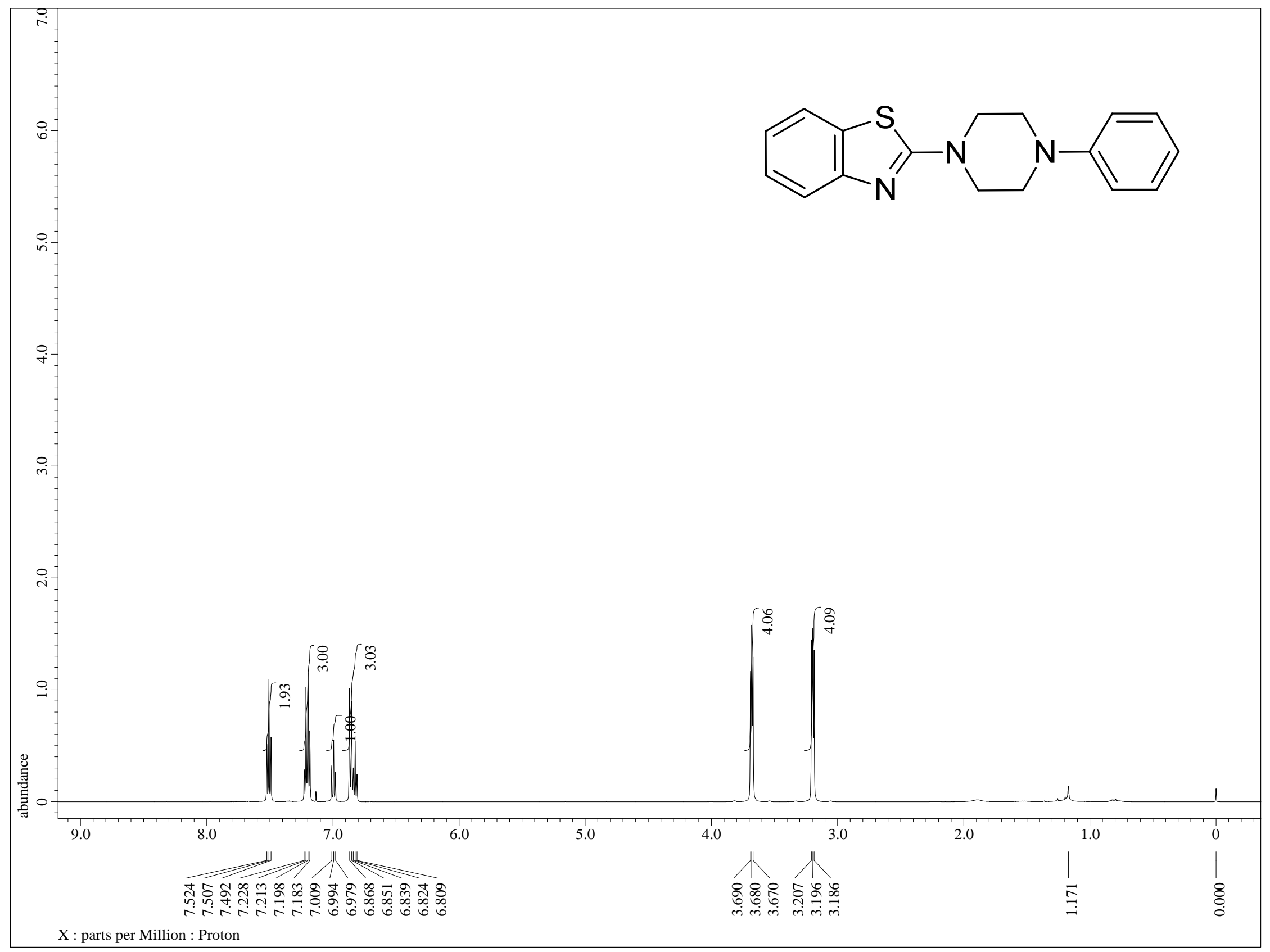

Figure S9: ${ }^{1} \mathrm{H}$ NMR (500 MHz, $\mathrm{CDCl}_{3}$ ) of compound $2 \mathbf{e}$ 


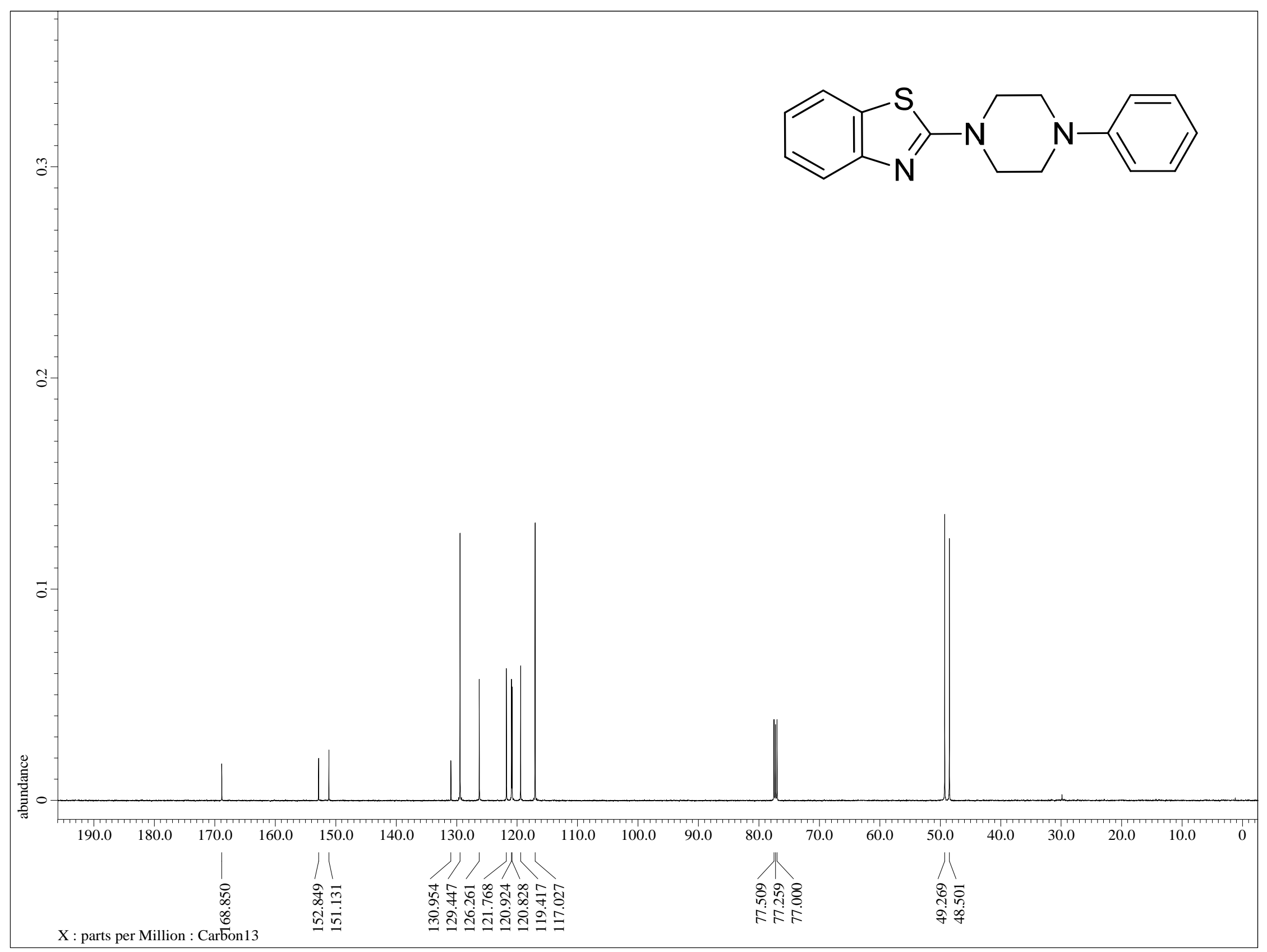

Figure S10: ${ }^{13} \mathrm{C}$ NMR (125 MHz, $\left.\mathrm{CDCl}_{3}\right)$ of compound $2 \mathbf{e}$ 


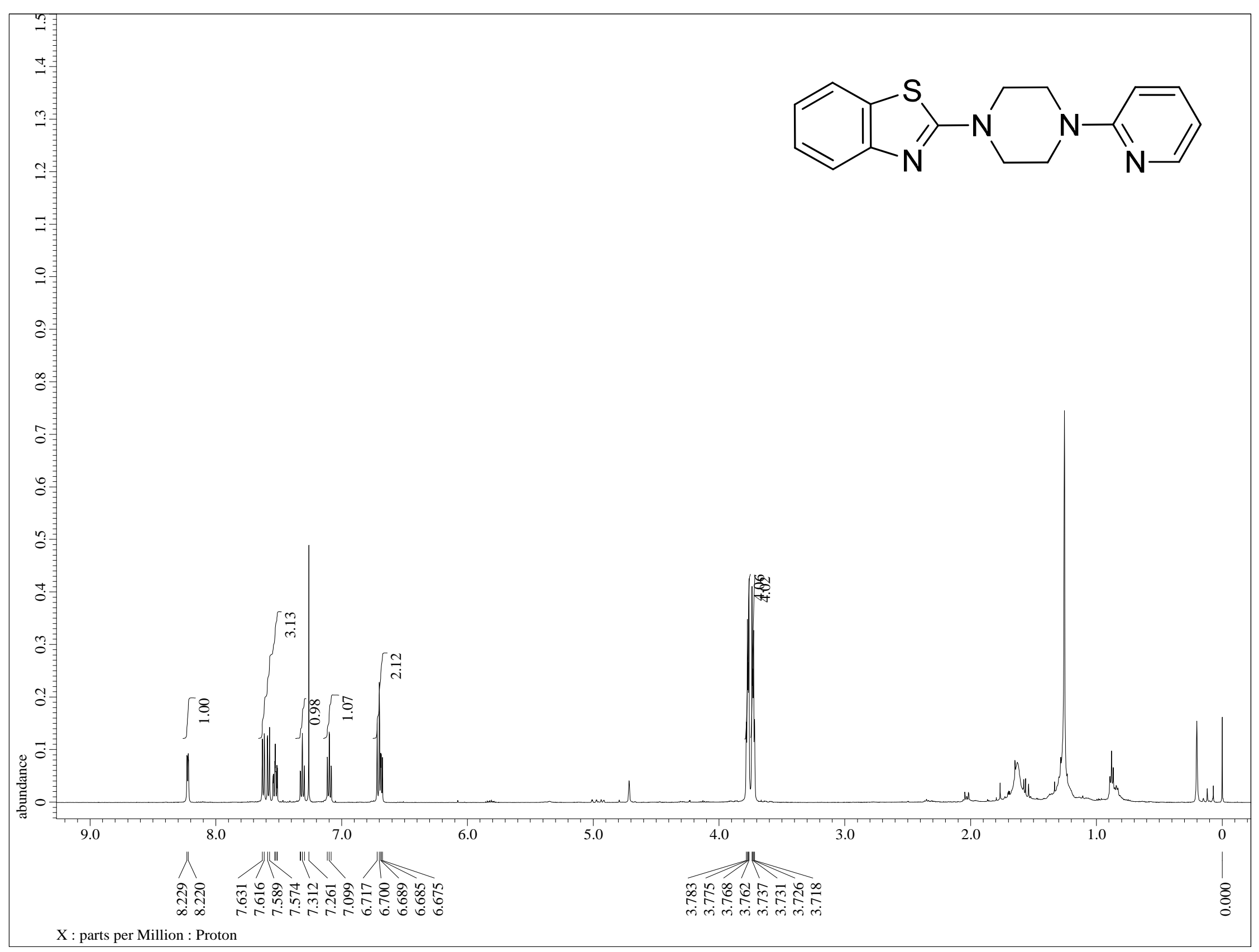

Figure S11: ${ }^{1} \mathrm{H}$ NMR $\left(500 \mathrm{MHz}, \mathrm{CDCl}_{3}\right)$ of compound 2f 


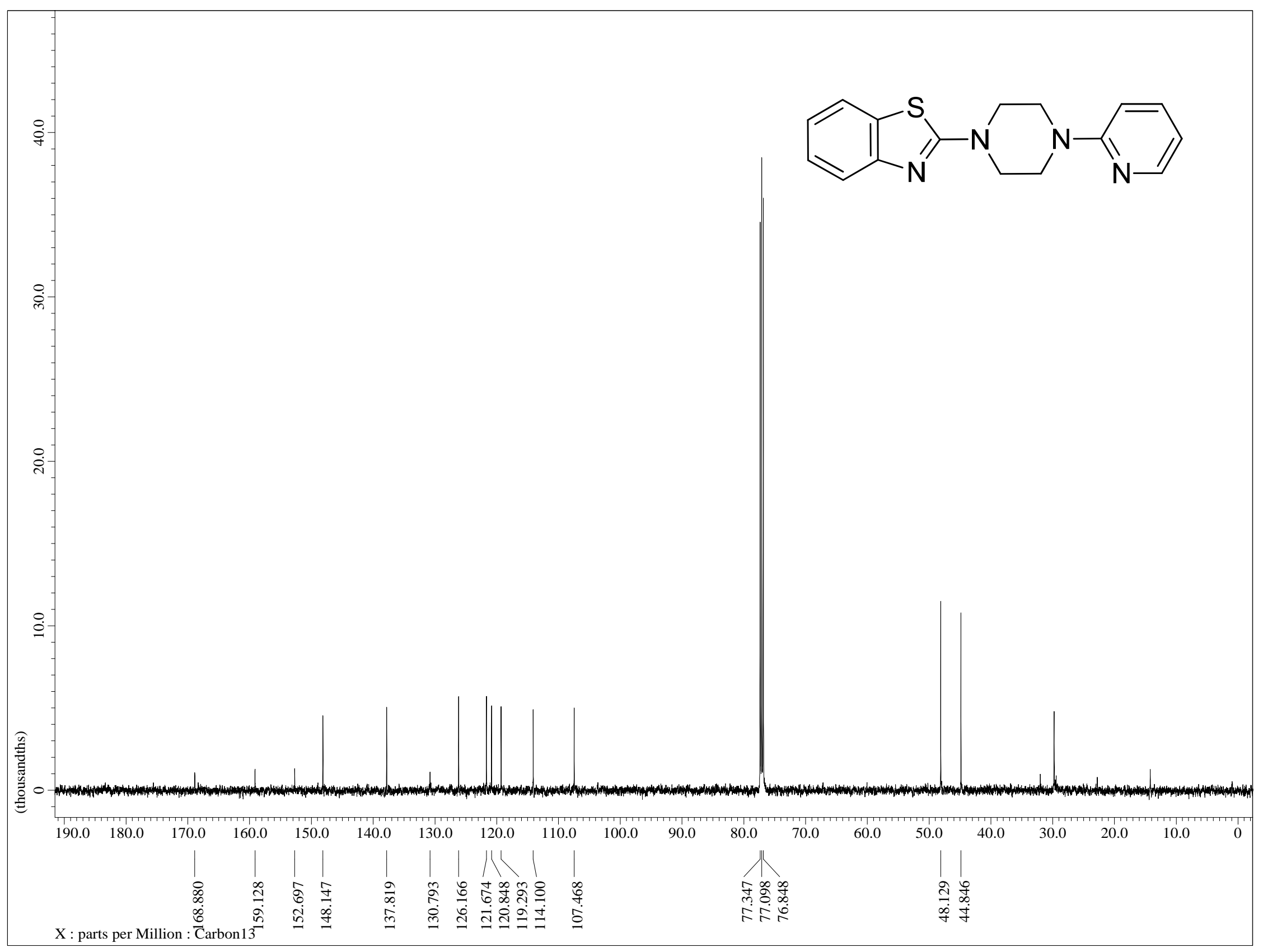

Figure S12: ${ }^{13} \mathrm{C}$ NMR (125 MHz, $\mathrm{CDCl}_{3}$ ) of compound $2 f$ 


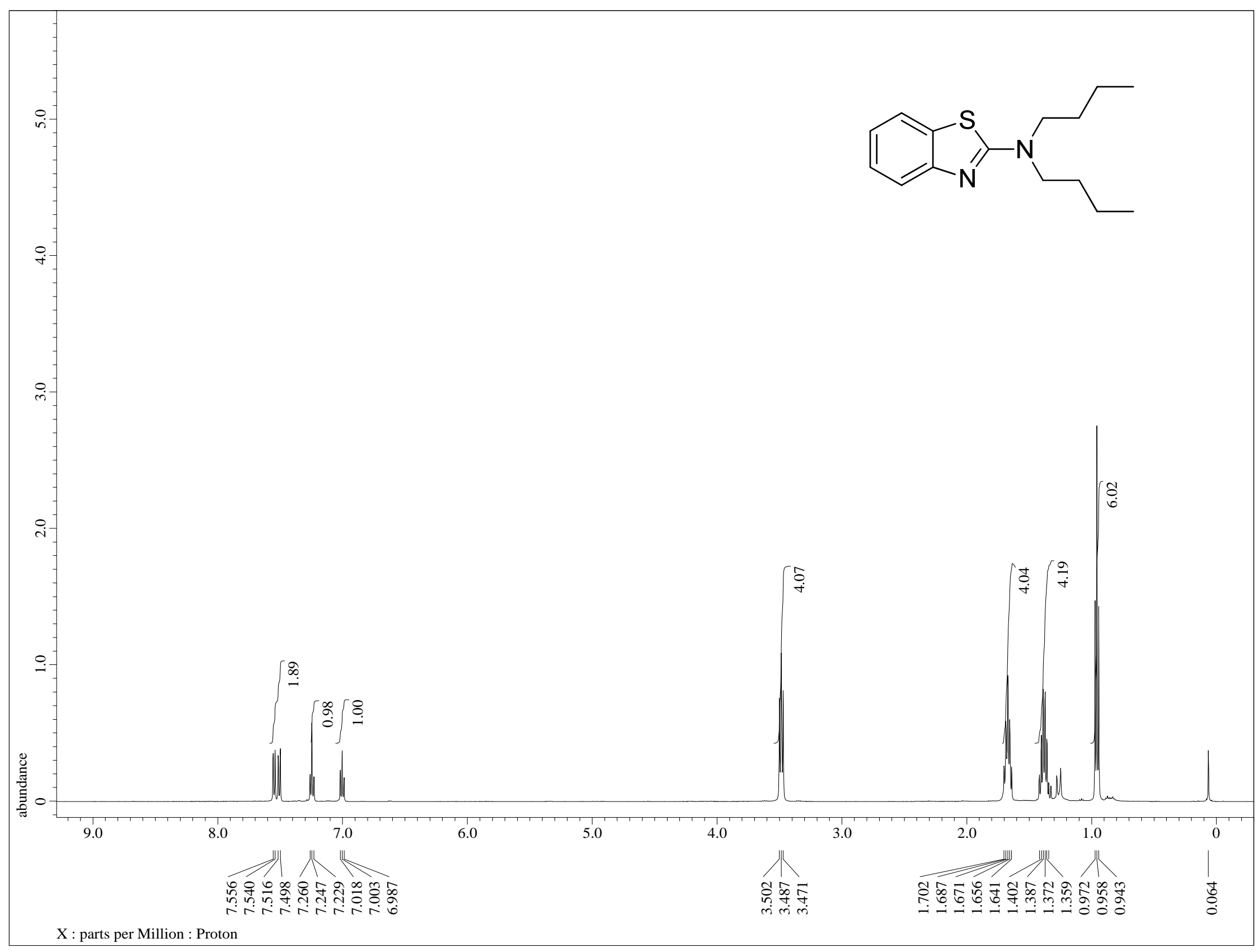

Figure S13: ${ }^{1} \mathrm{H}$ NMR (500 MHz, $\mathrm{CDCl}_{3}$ ) of compound $\mathbf{2 g}$ 


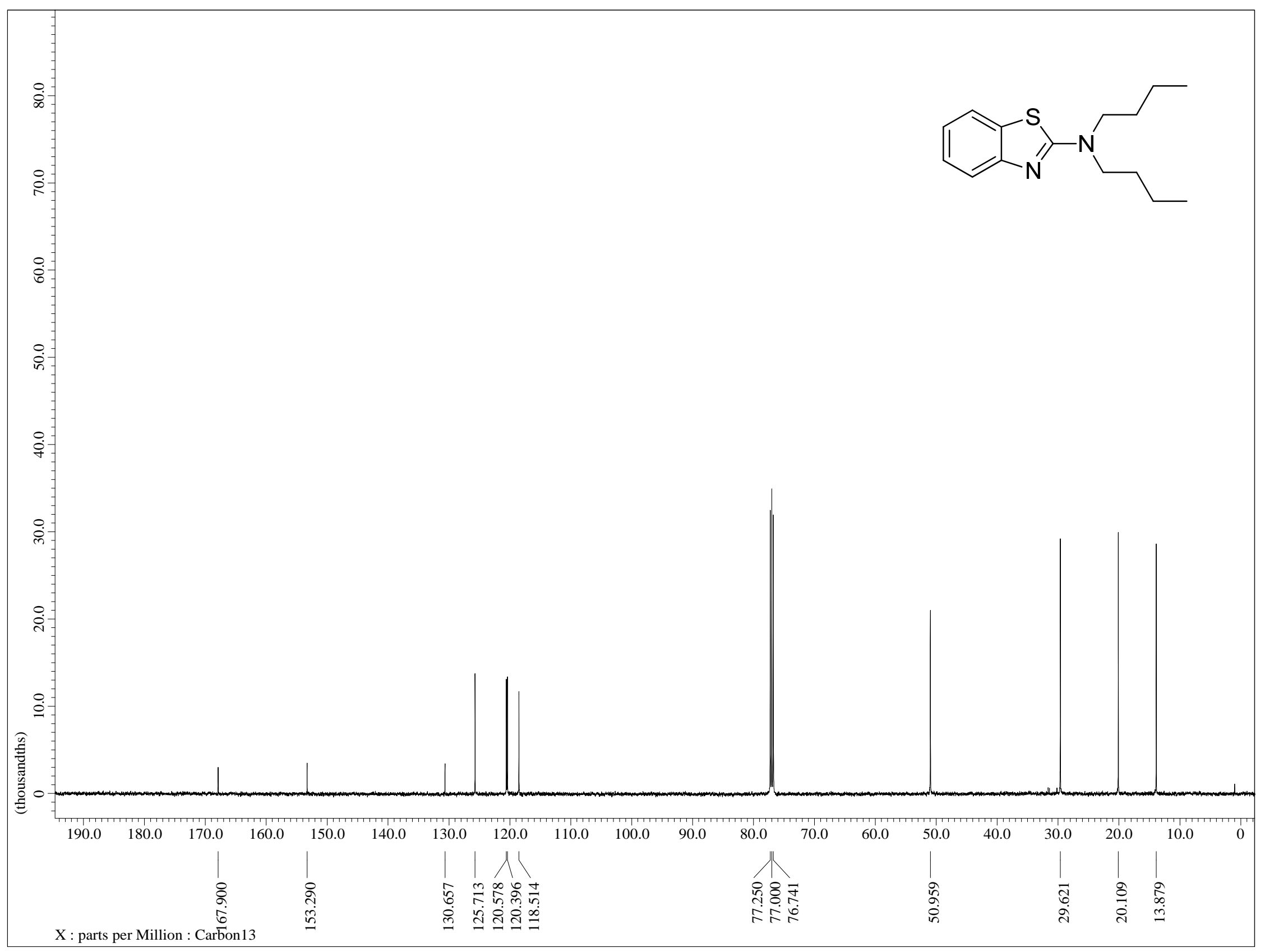

Figure S14: ${ }^{13} \mathrm{C}$ NMR (125 MHz, $\left.\mathrm{CDCl}_{3}\right)$ of compound $\mathbf{2 g}$ 


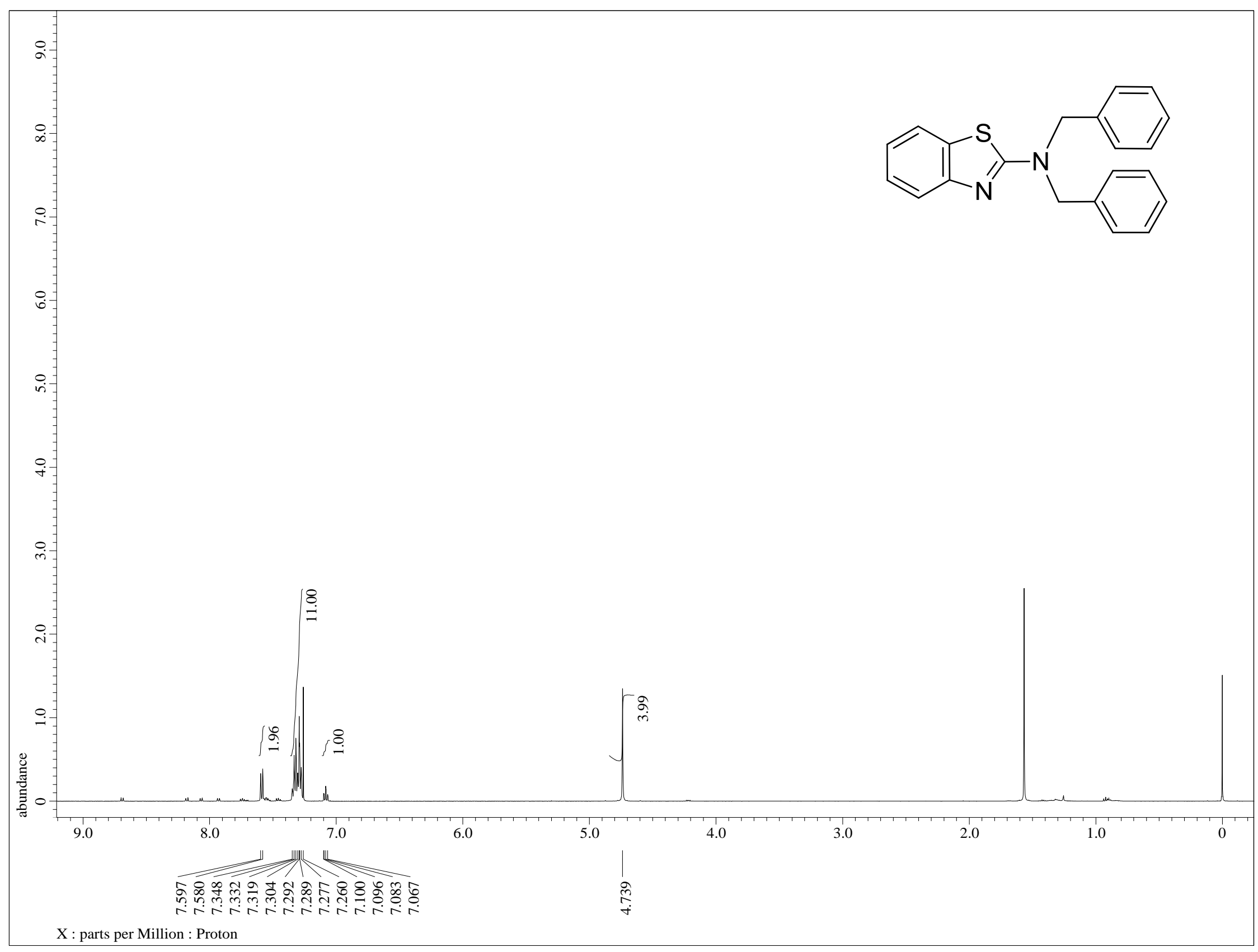

Figure S15: ${ }^{1} \mathrm{H}$ NMR (500 MHz, $\left.\mathrm{CDCl}_{3}\right)$ of compound $\mathbf{2 h}$ 


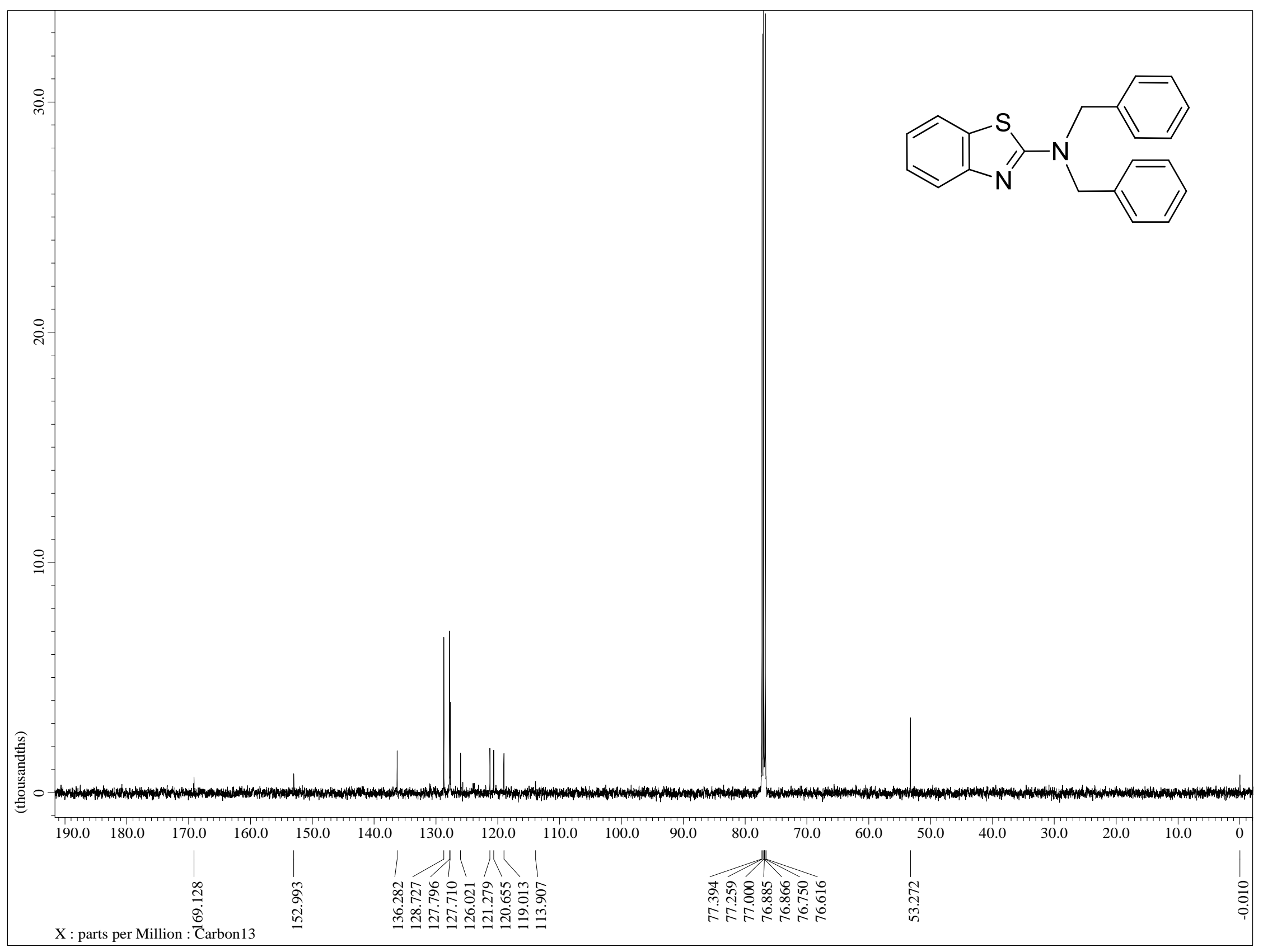

Figure S16: ${ }^{13} \mathrm{C}$ NMR $\left(125 \mathrm{MHz}, \mathrm{CDCl}_{3}\right.$ ) of compound $\mathbf{2 h}$ 


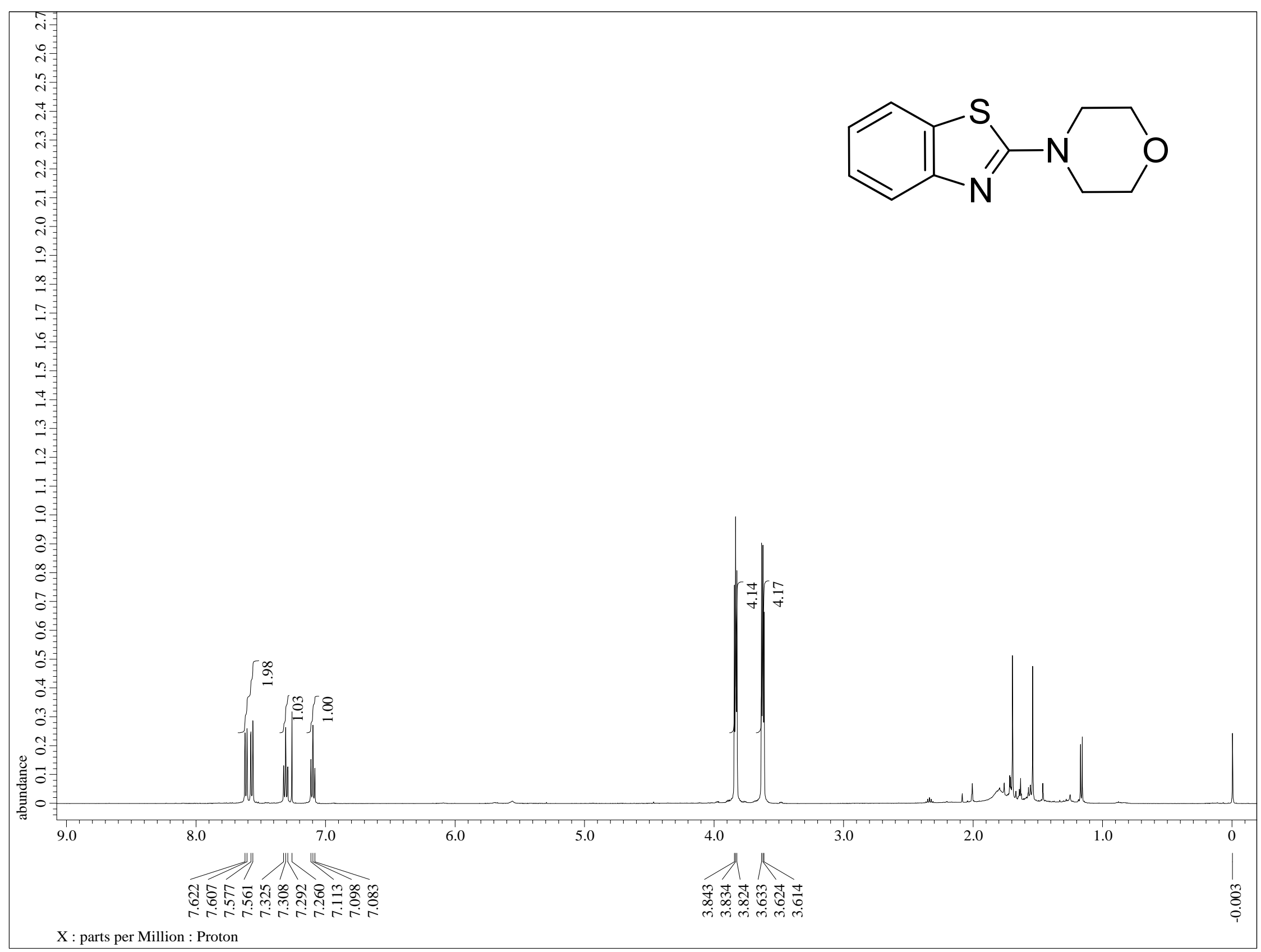

Figure S17: ${ }^{1} \mathrm{H}$ NMR $\left(500 \mathrm{MHz}, \mathrm{CDCl}_{3}\right)$ of compound 2i 


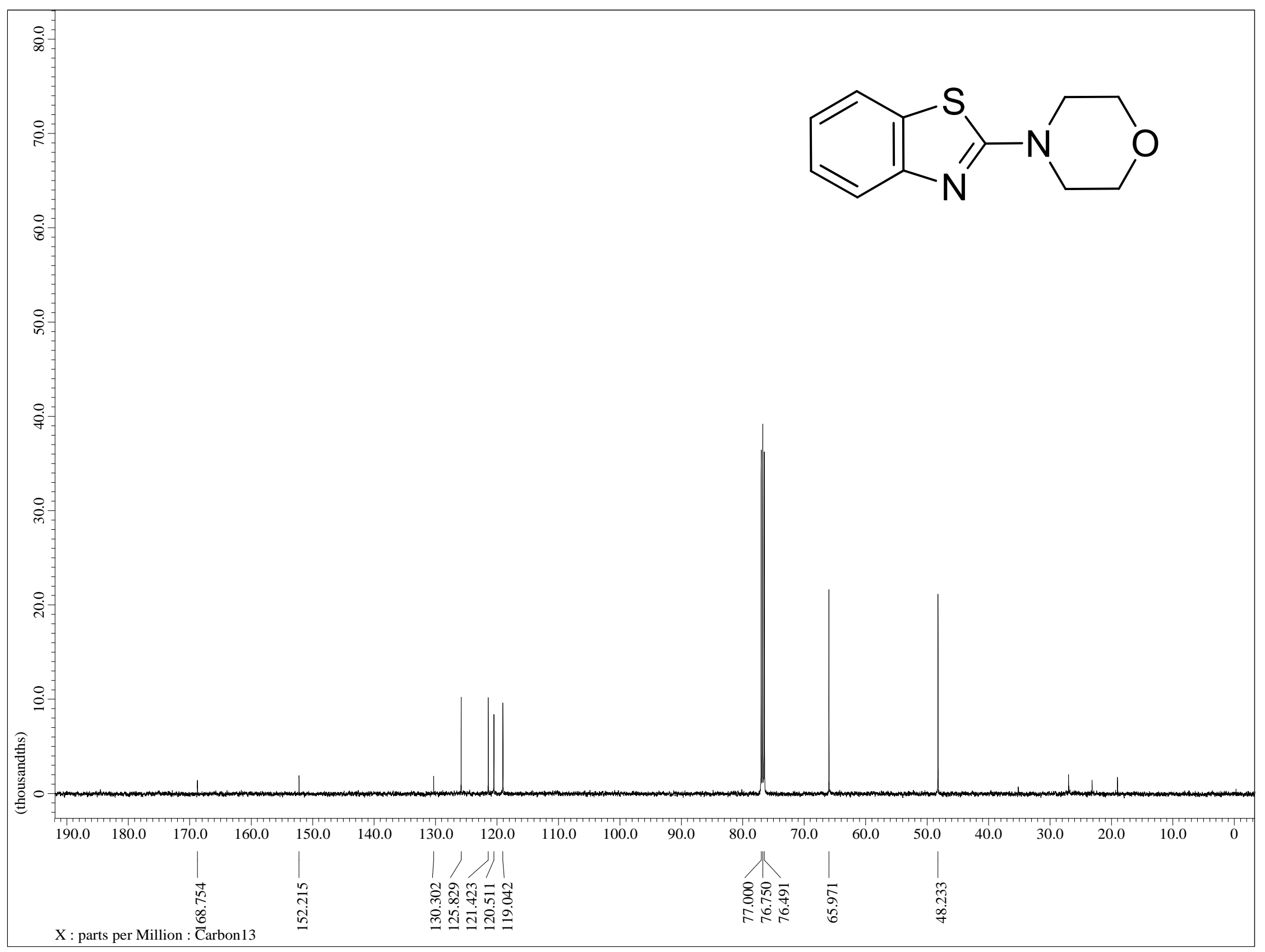

Figure S18: ${ }^{13} \mathrm{C}$ NMR (125 MHz, $\mathrm{CDCl}_{3}$ ) of compound 2i 


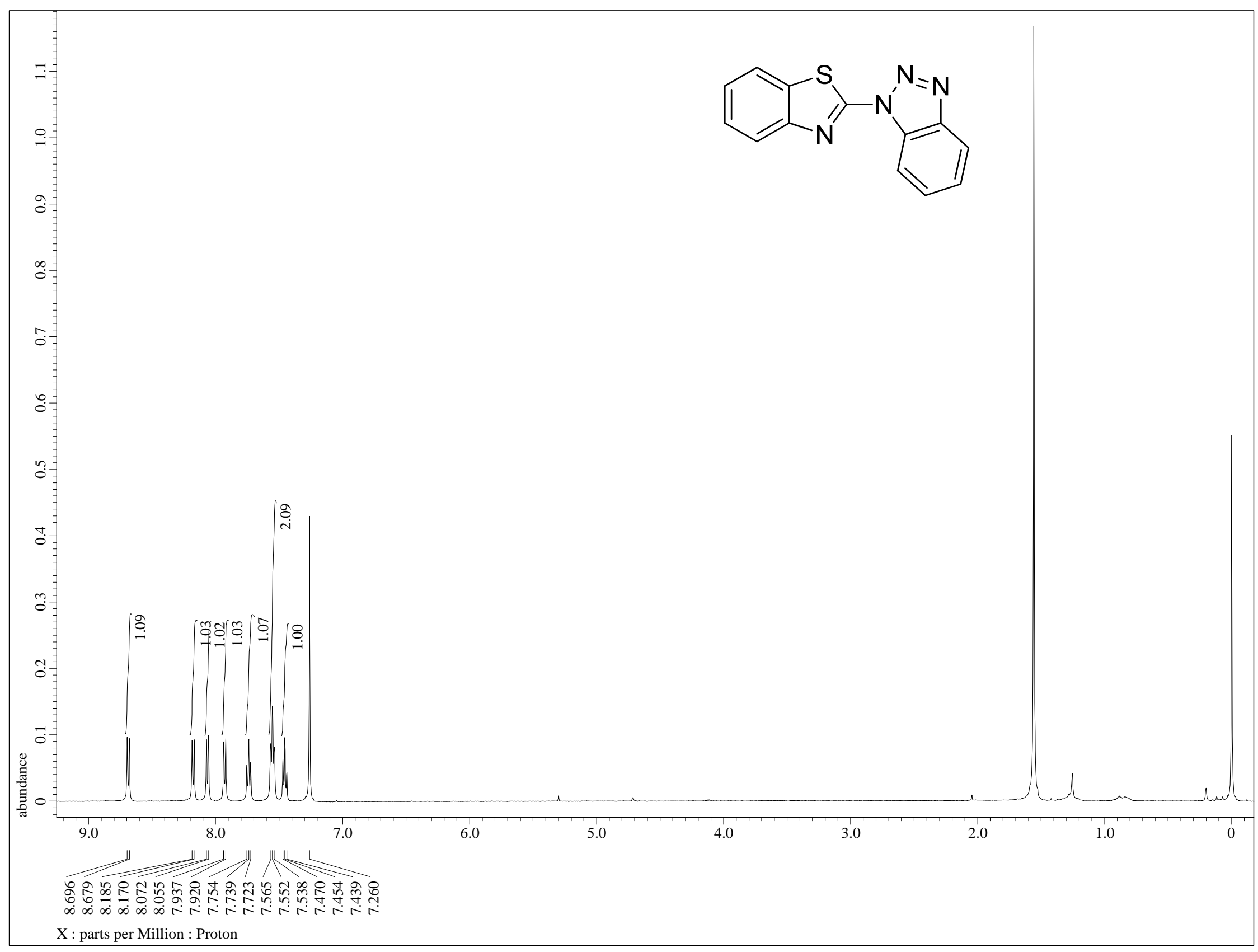

Figure S19: ${ }^{1} \mathrm{H}$ NMR $\left(500 \mathrm{MHz}, \mathrm{CDCl}_{3}\right)$ of compound $\mathbf{2 j}$ 


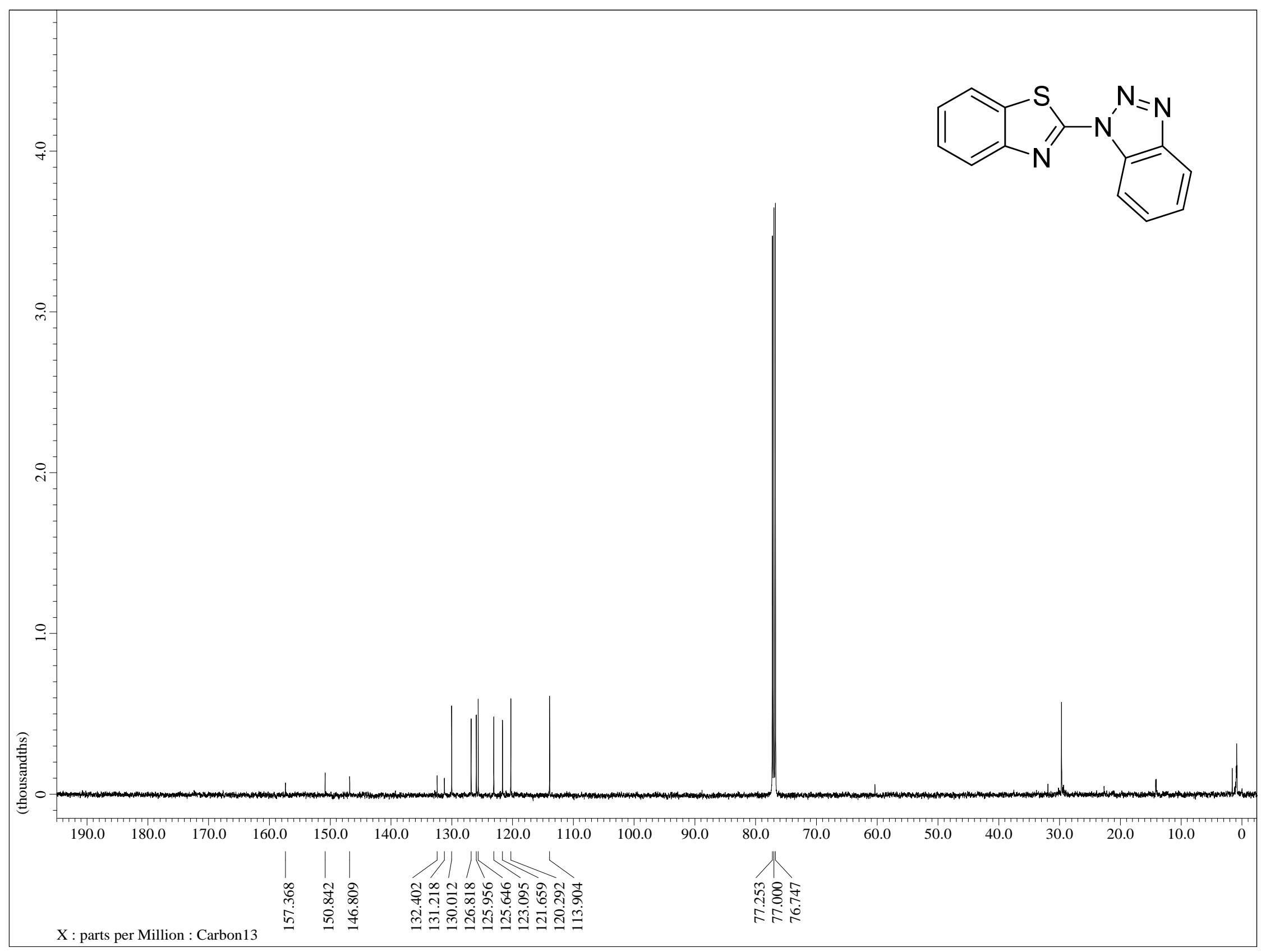

Figure S20: ${ }^{13} \mathrm{C}$ NMR (125 MHz, $\mathrm{CDCl}_{3}$ ) of compound $\mathbf{2 j}$ 


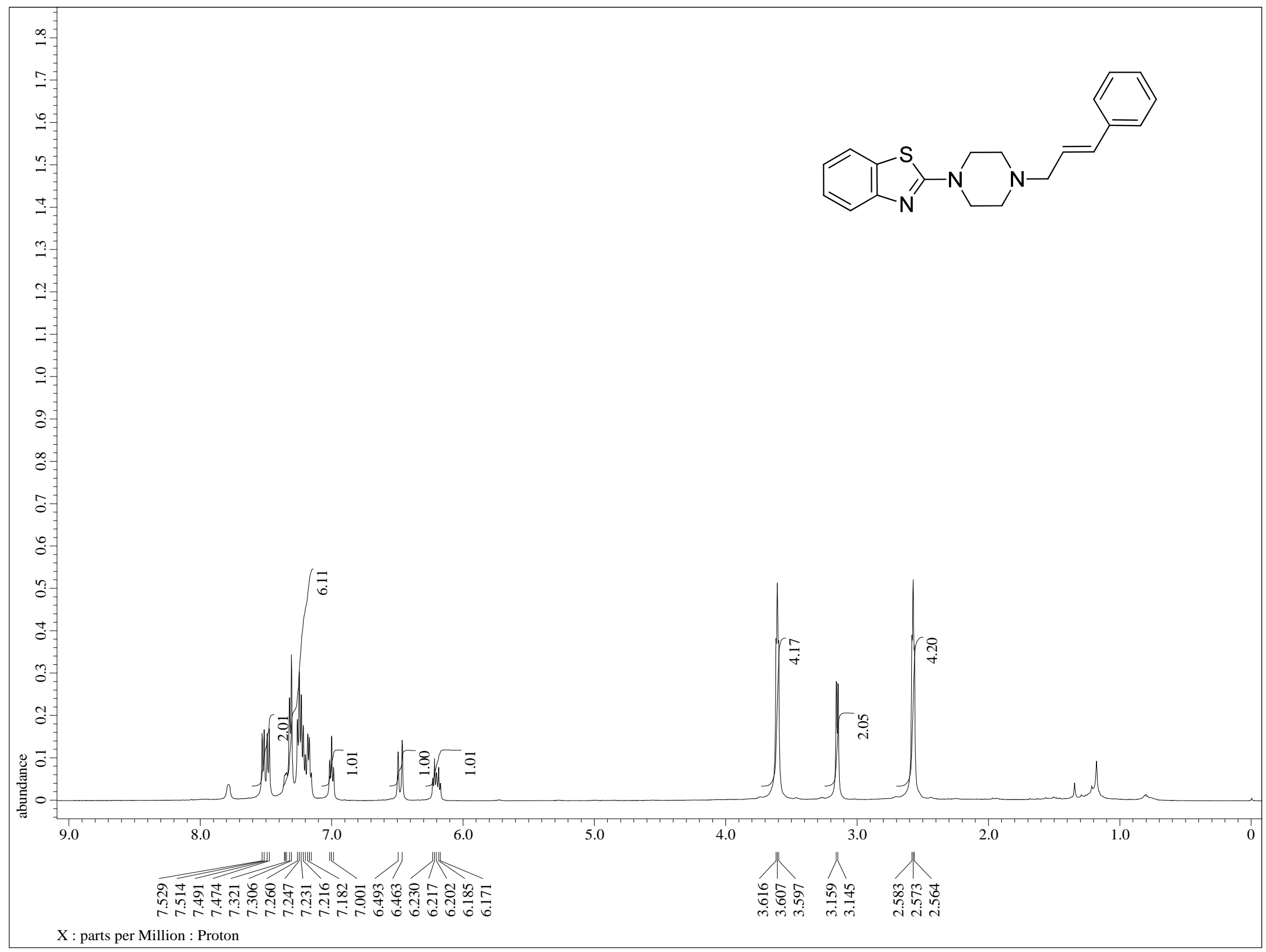

Figure S21: ${ }^{1} \mathrm{H}$ NMR $\left(500 \mathrm{MHz}, \mathrm{CDCl}_{3}\right)$ of compound $\mathbf{2 k}$ 


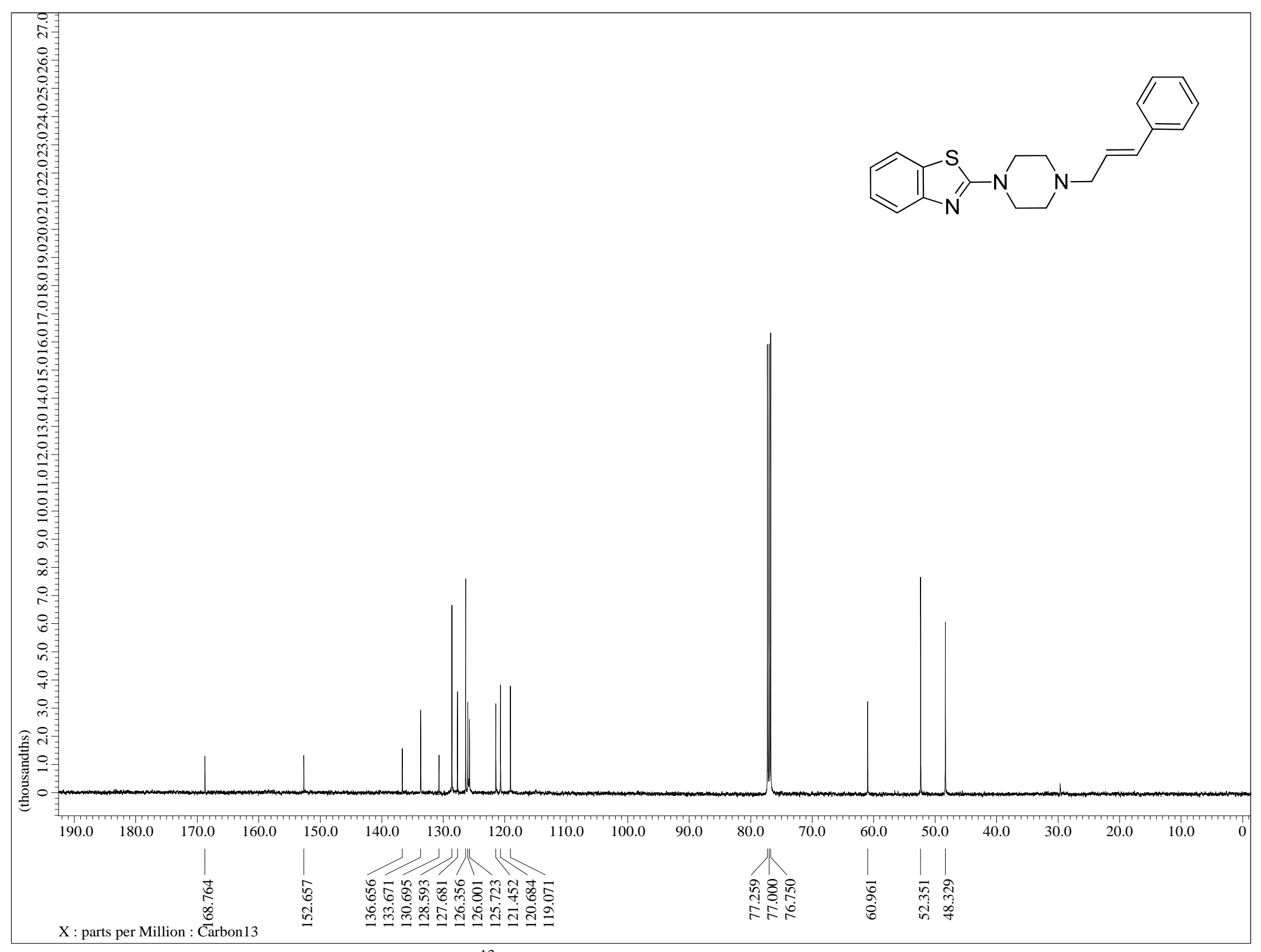

Figure S22: ${ }^{13} \mathrm{C}$ NMR $\left(125 \mathrm{MHz}, \mathrm{CDCl}_{3}\right)$ of compound $\mathbf{2 k}$ 


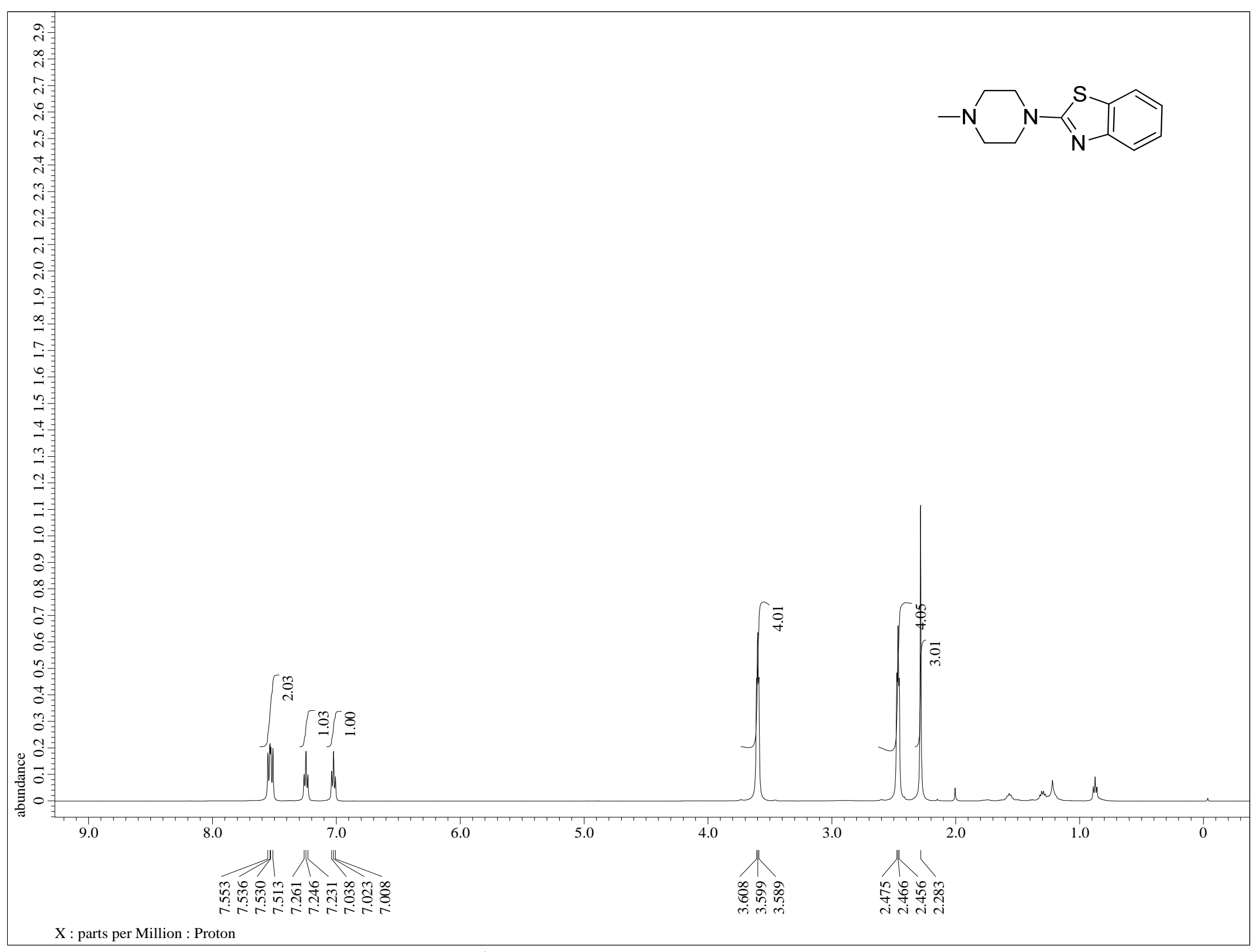

Figure S23: ${ }^{1} \mathrm{H} \mathrm{NMR}\left(500 \mathrm{MHz}, \mathrm{CDCl}_{3}\right)$ of compound $2 \mathbf{l}$ 


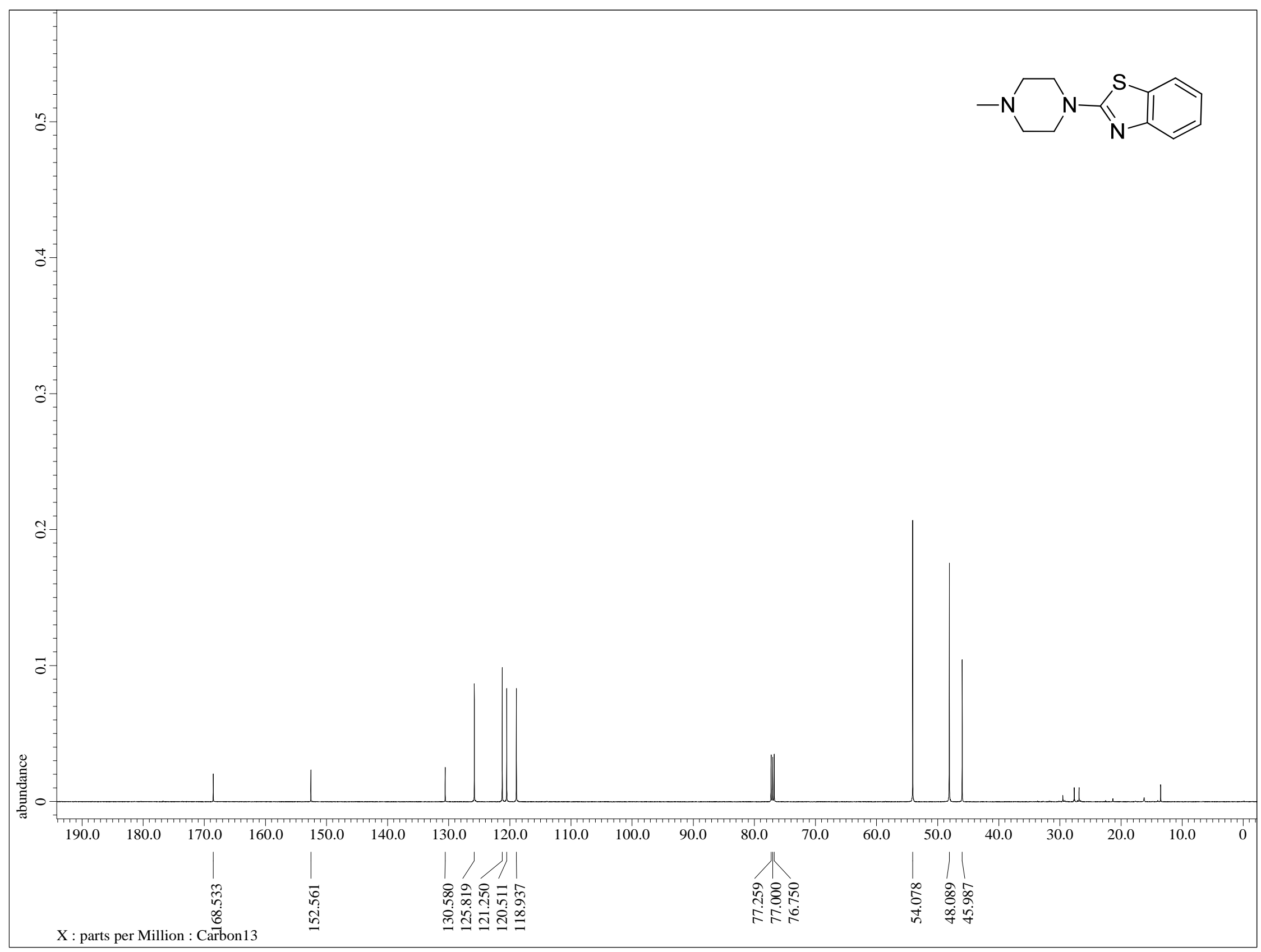

Figure S24: ${ }^{13} \mathrm{C}$ NMR (125 MHz, $\mathrm{CDCl}_{3}$ ) of compound 2l 


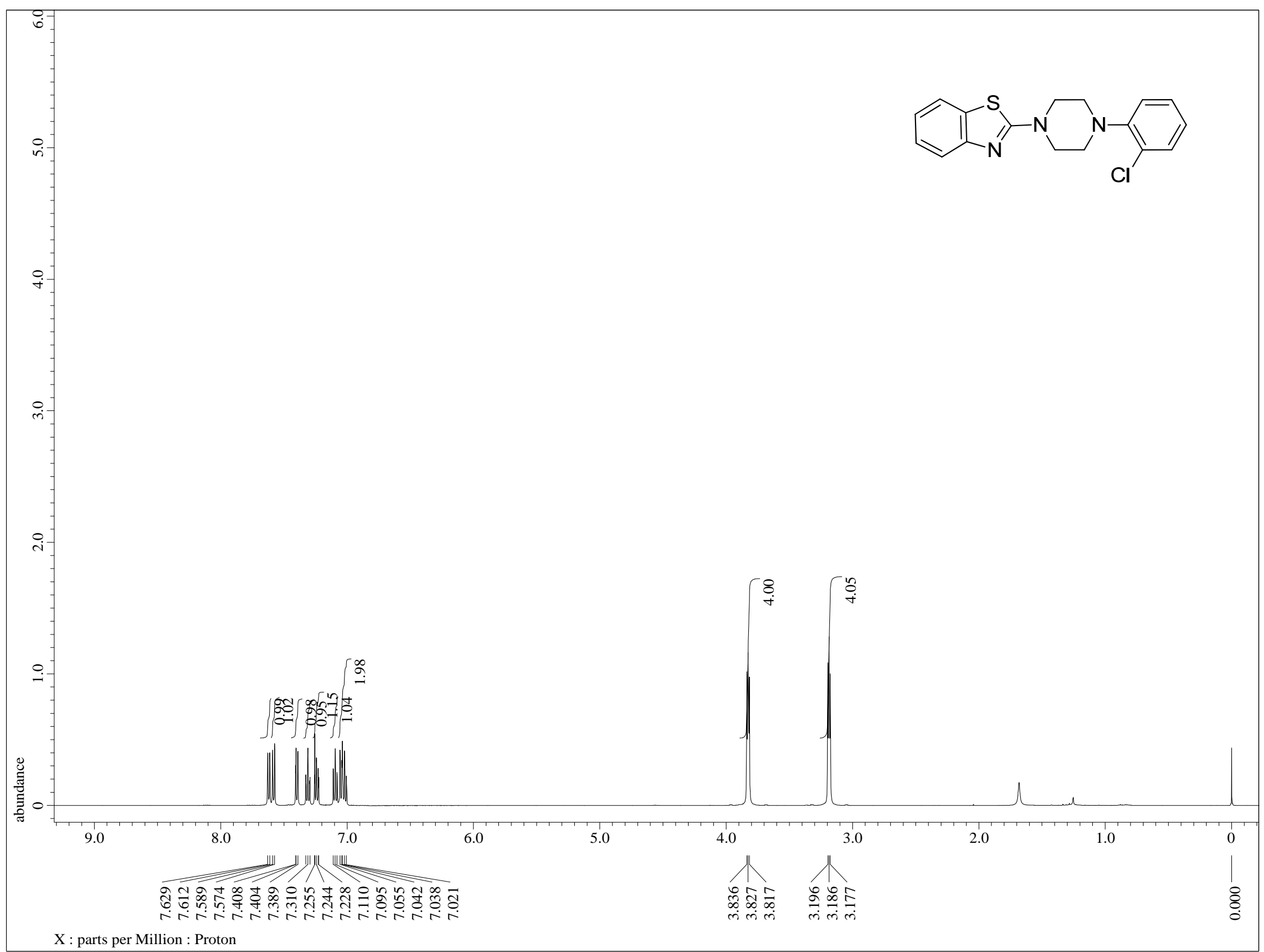

Figure S25: ${ }^{1} \mathrm{H}$ NMR $\left(500 \mathrm{MHz}, \mathrm{CDCl}_{3}\right)$ of compound $\mathbf{2 m}$ 


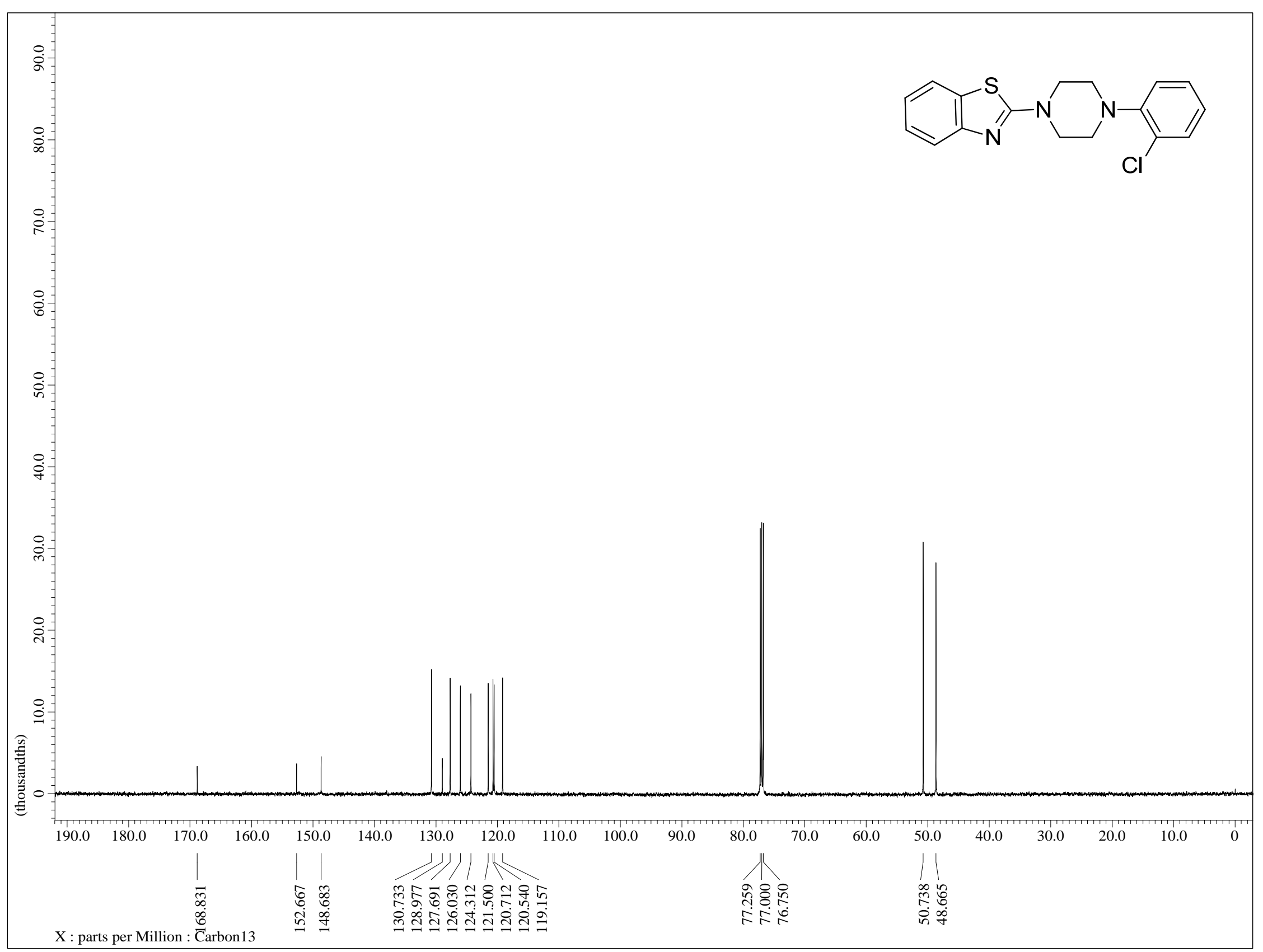

Figure S26: ${ }^{13} \mathrm{C}$ NMR $\left(125 \mathrm{MHz}, \mathrm{CDCl}_{3}\right)$ of compound $\mathbf{2 m}$ 


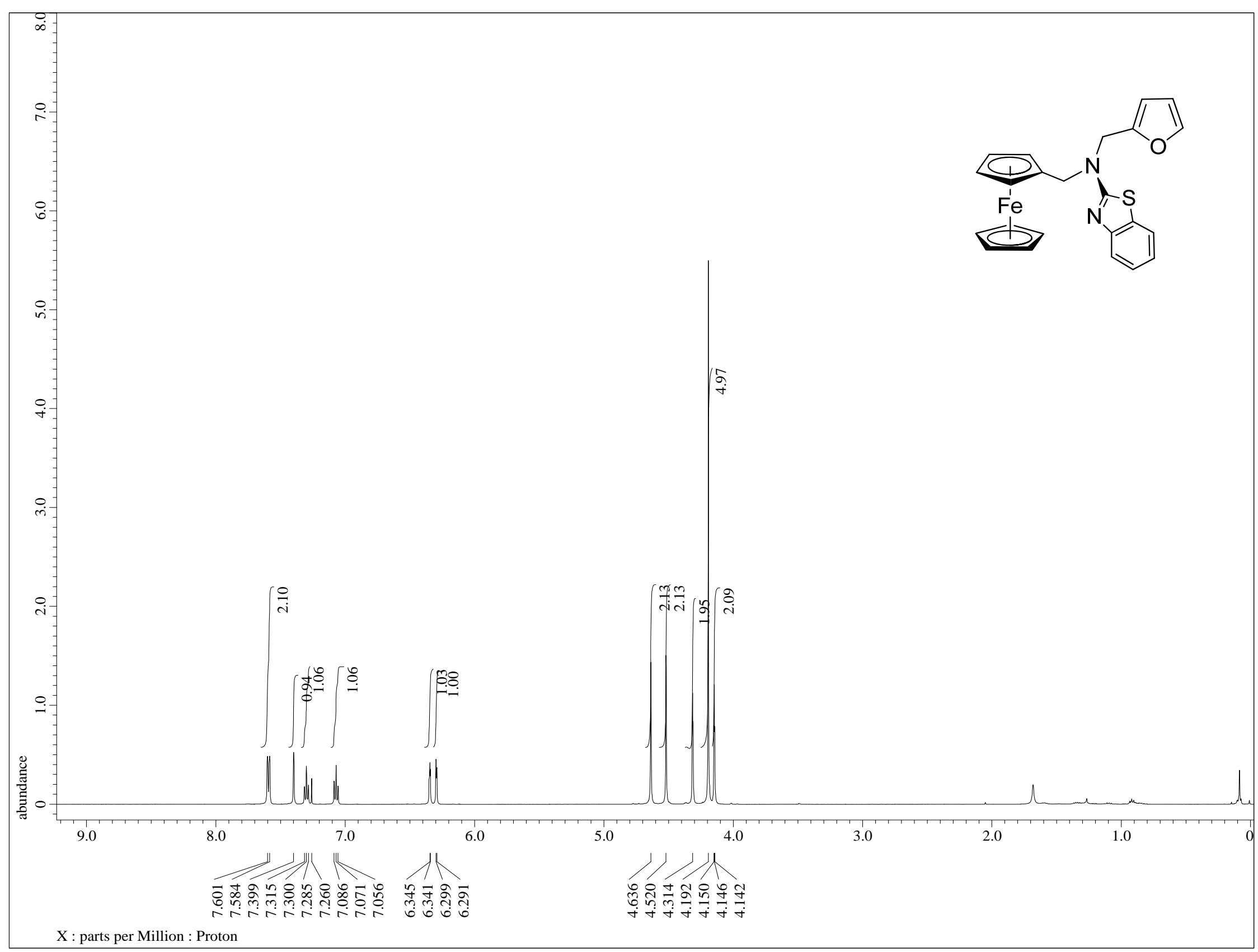

Figure S27: ${ }^{1} \mathrm{H}$ NMR (500 MHz, $\mathrm{CDCl}_{3}$ ) of compound 2n 


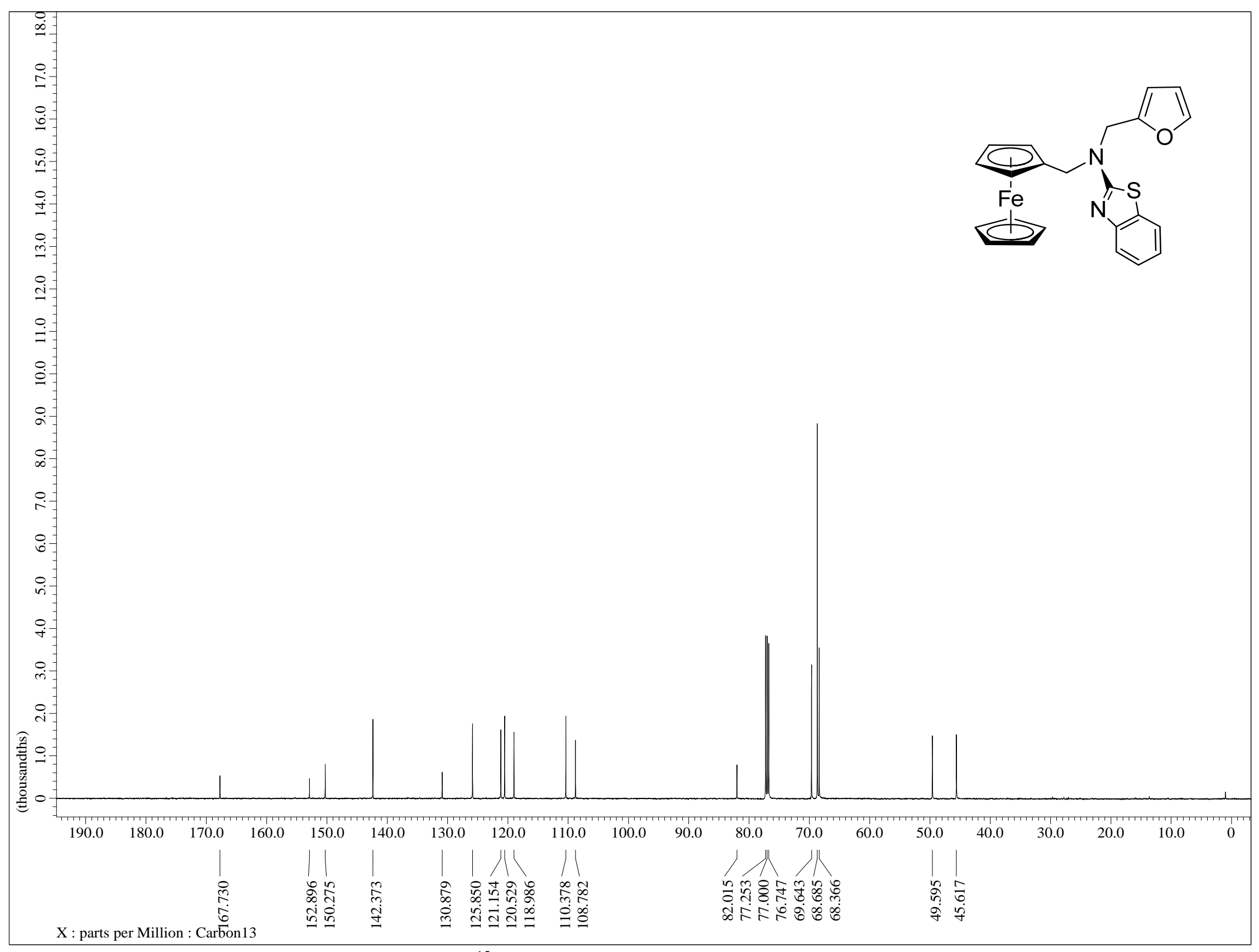

Figure S28: ${ }^{13} \mathrm{C}$ NMR (125 MHz, $\left.\mathrm{CDCl}_{3}\right)$ of compound 2n 


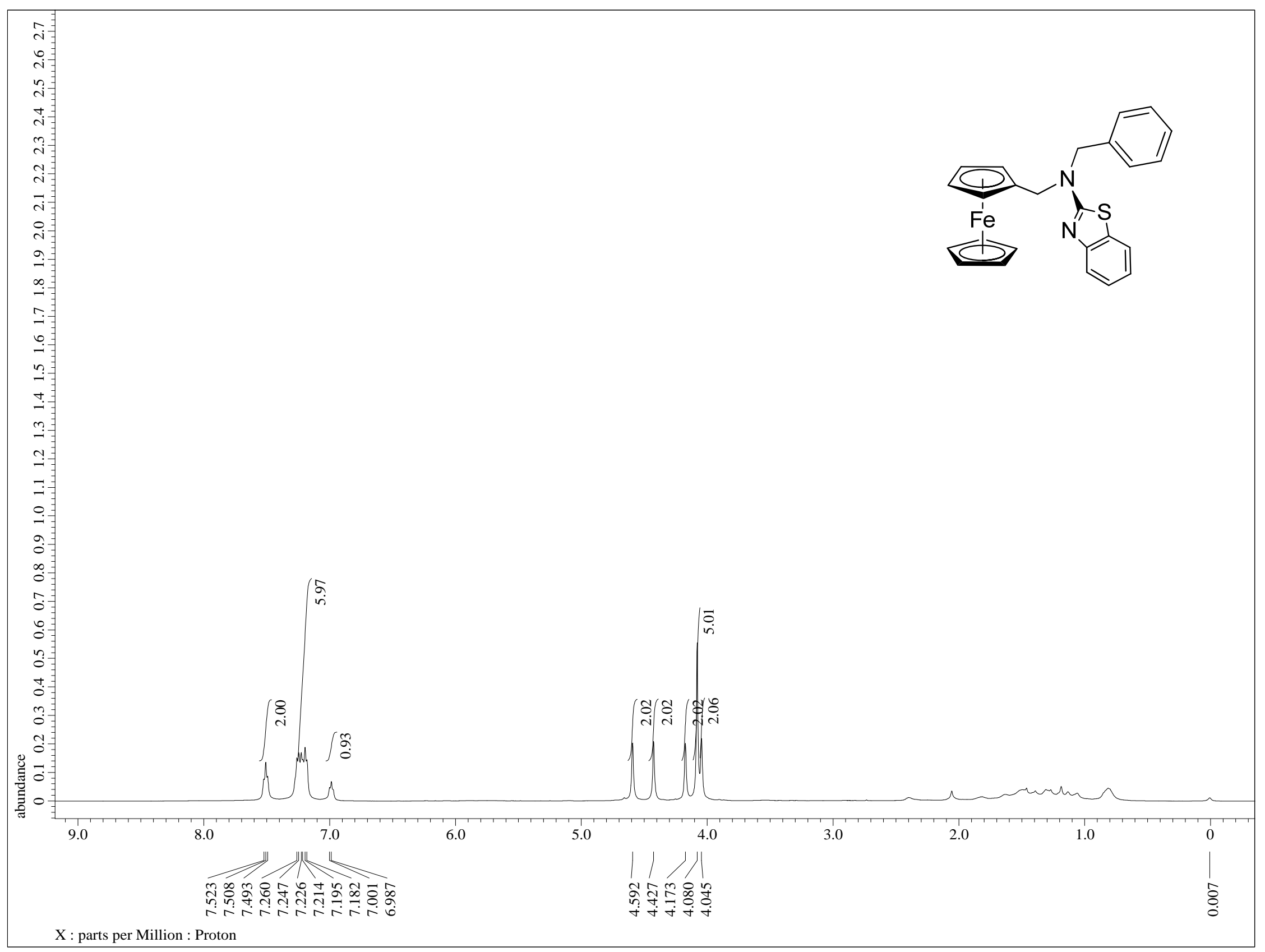

Figure S29: ${ }^{1} \mathrm{H}$ NMR $\left(500 \mathrm{MHz}, \mathrm{CDCl}_{3}\right.$ ) of compound 20 


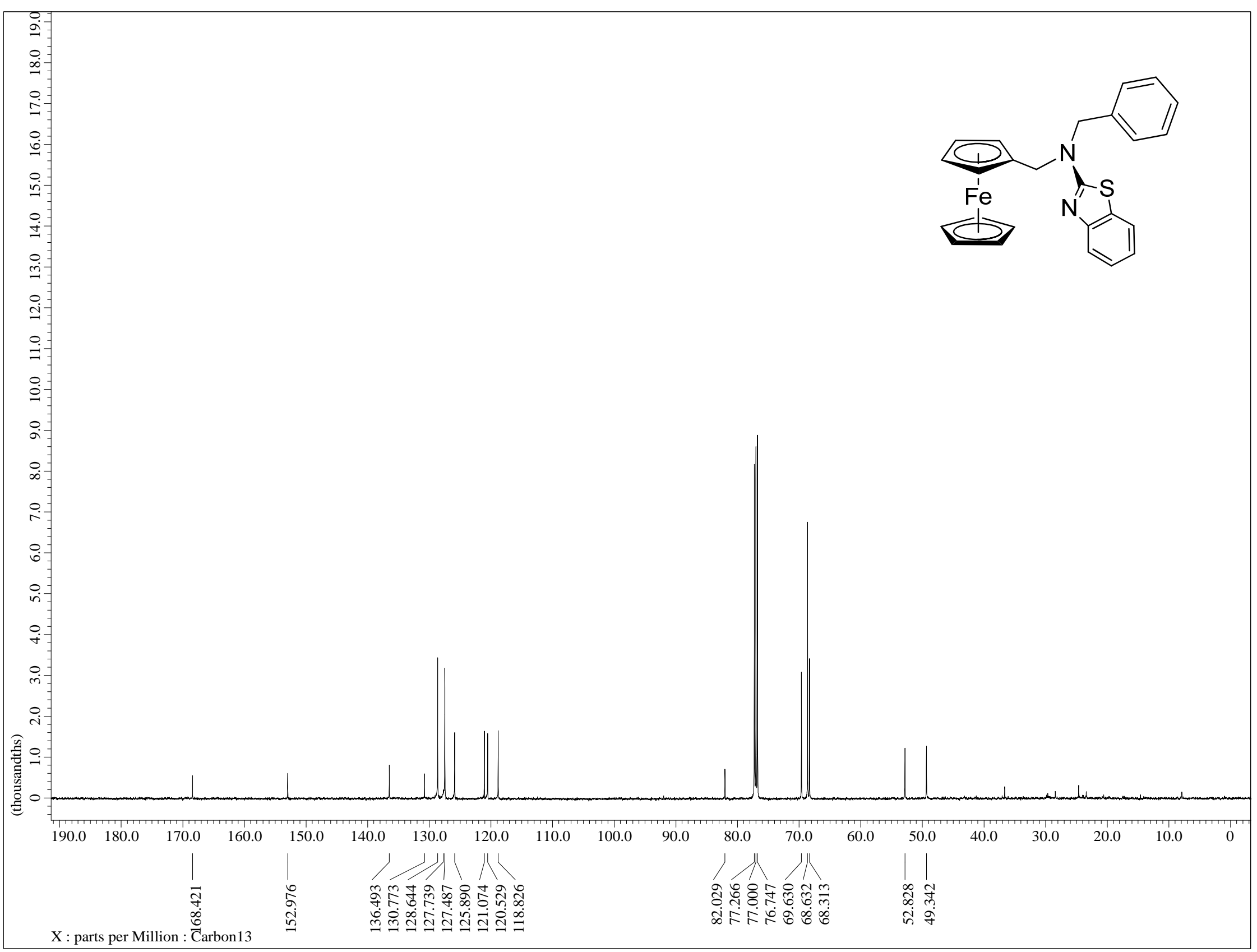

Figure S30: ${ }^{13} \mathrm{C}$ NMR (125 MHz, $\mathrm{CDCl}_{3}$ ) of compound 2o 


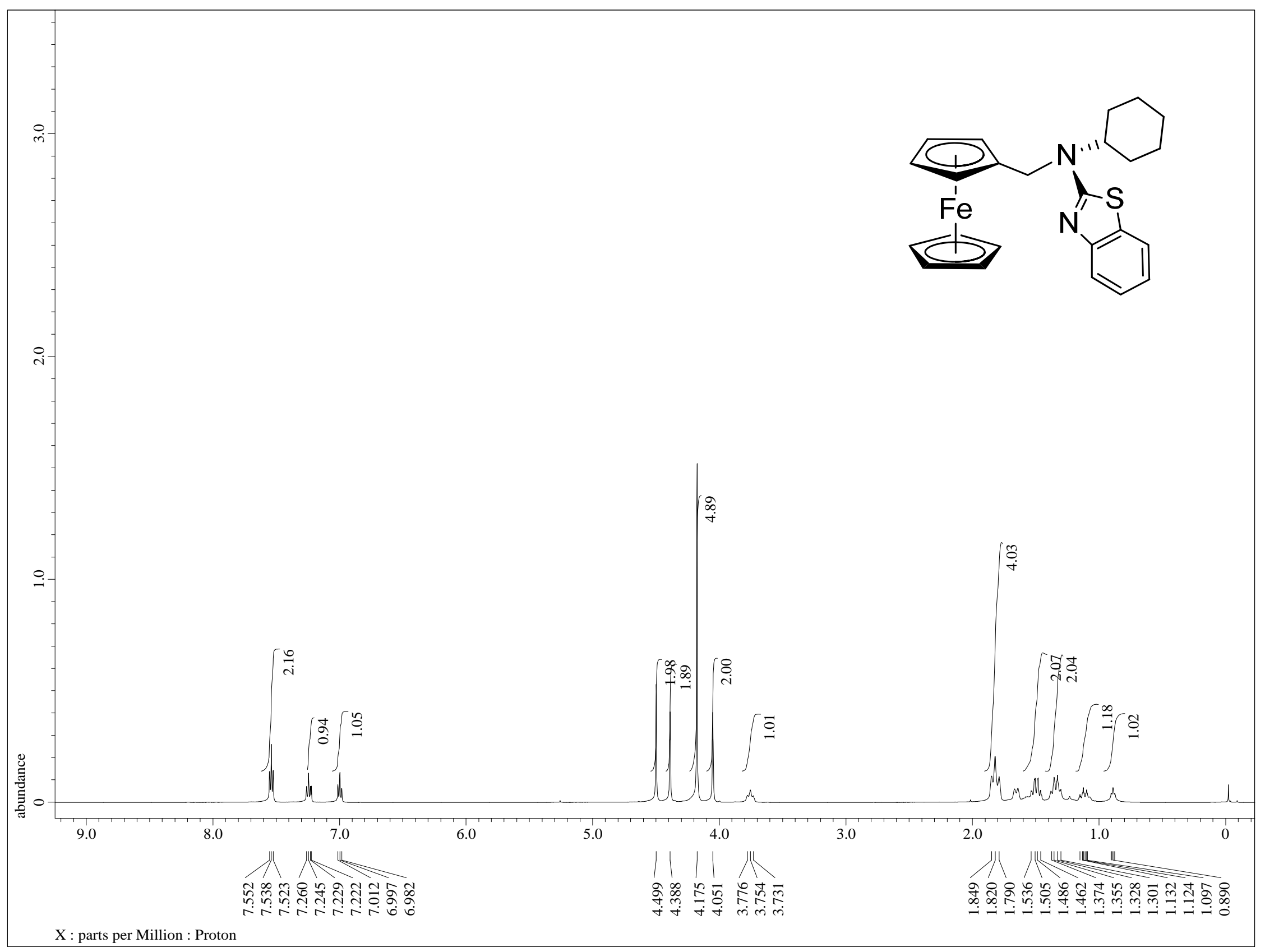

Figure S31: ${ }^{1} \mathrm{H}$ NMR (500 MHz, $\mathrm{CDCl}_{3}$ ) of compound 2p 


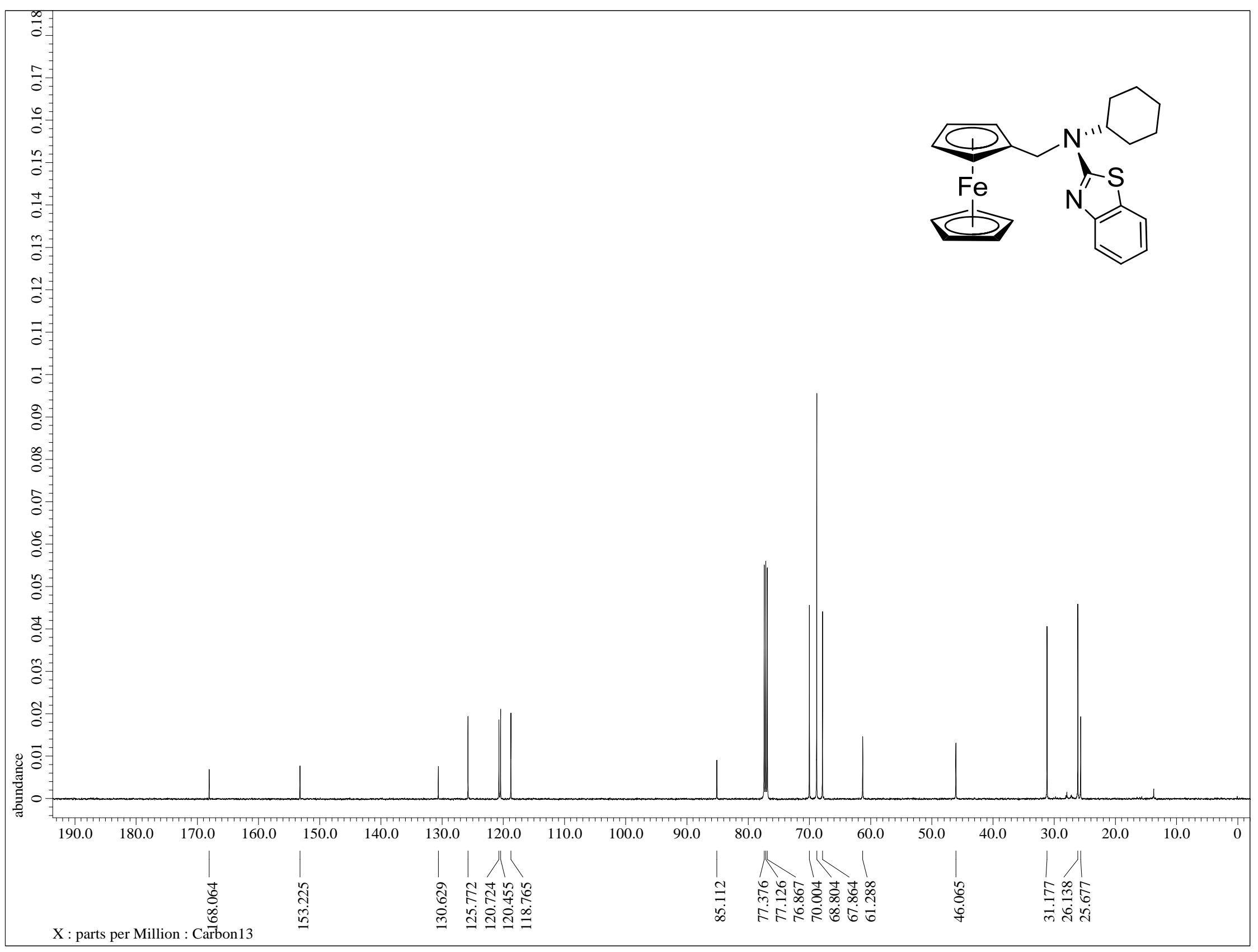

Figure S32: ${ }^{13} \mathrm{C}$ NMR (125 MHz, $\left.\mathrm{CDCl}_{3}\right)$ of compound 2p 


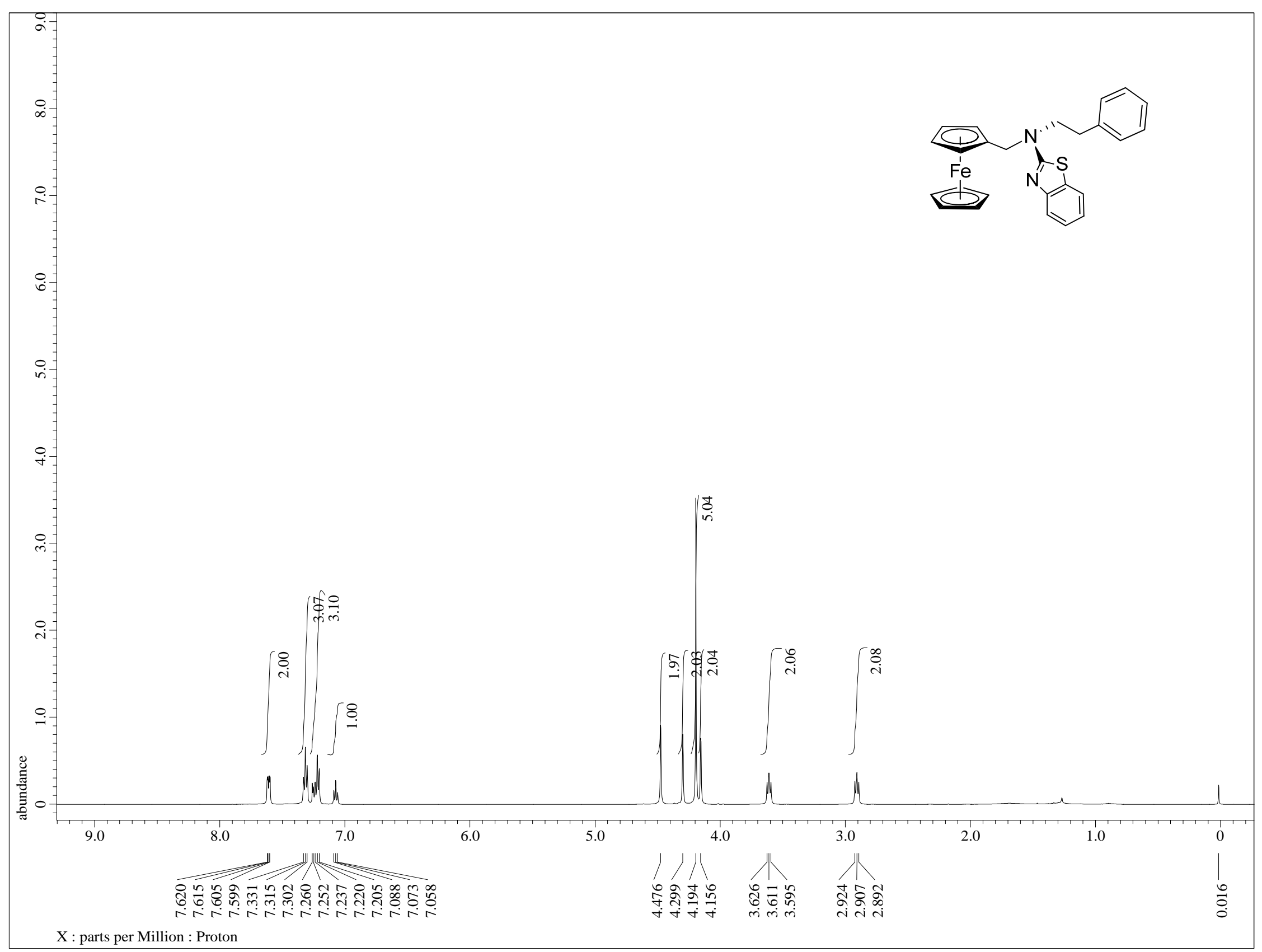

Figure S33: ${ }^{1} \mathrm{H}$ NMR (500 MHz, $\mathrm{CDCl}_{3}$ ) of compound 2q 


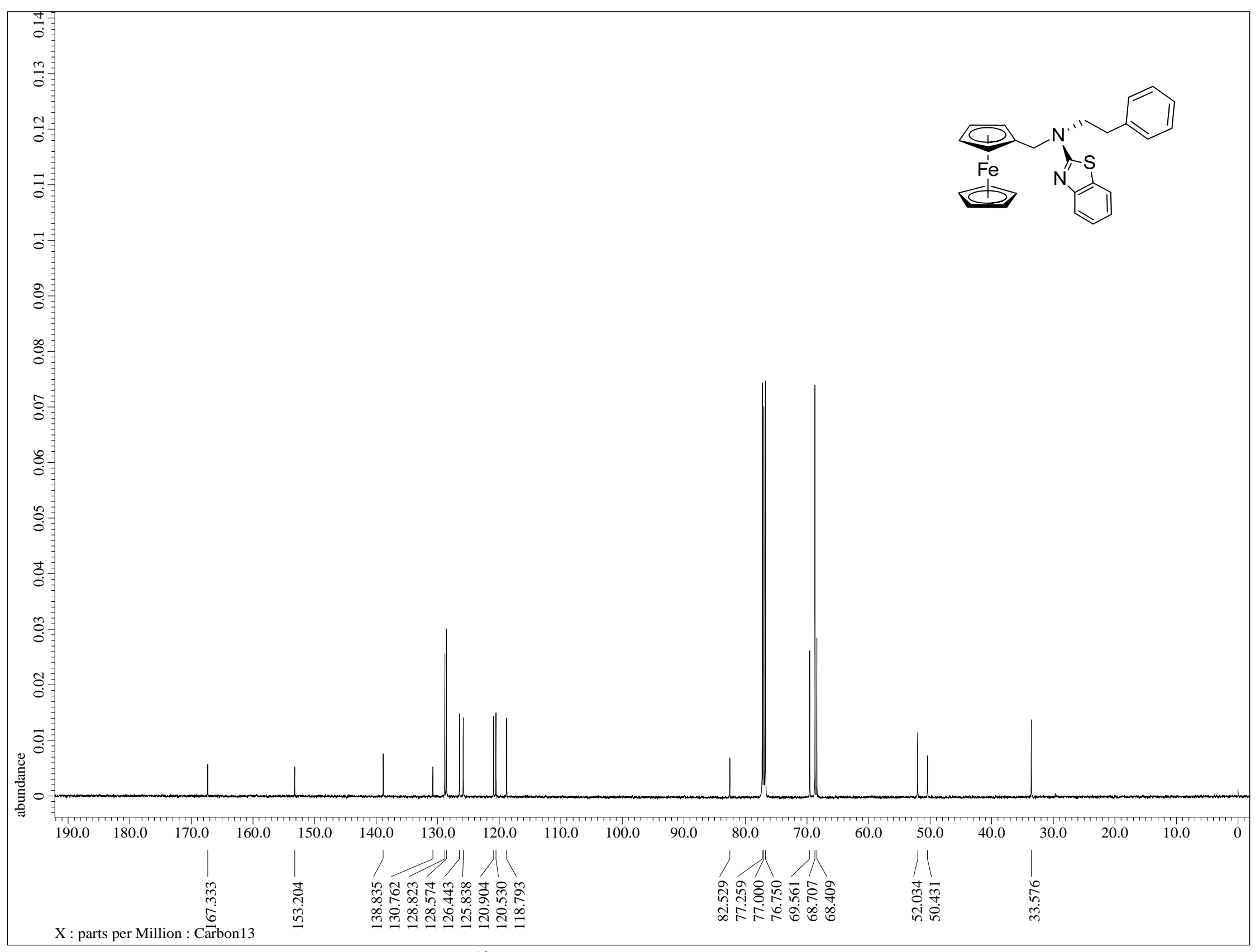

Figure S34: ${ }^{13} \mathrm{C}$ NMR (125 MHz, $\mathrm{CDCl}_{3}$ ) of compound 2q 


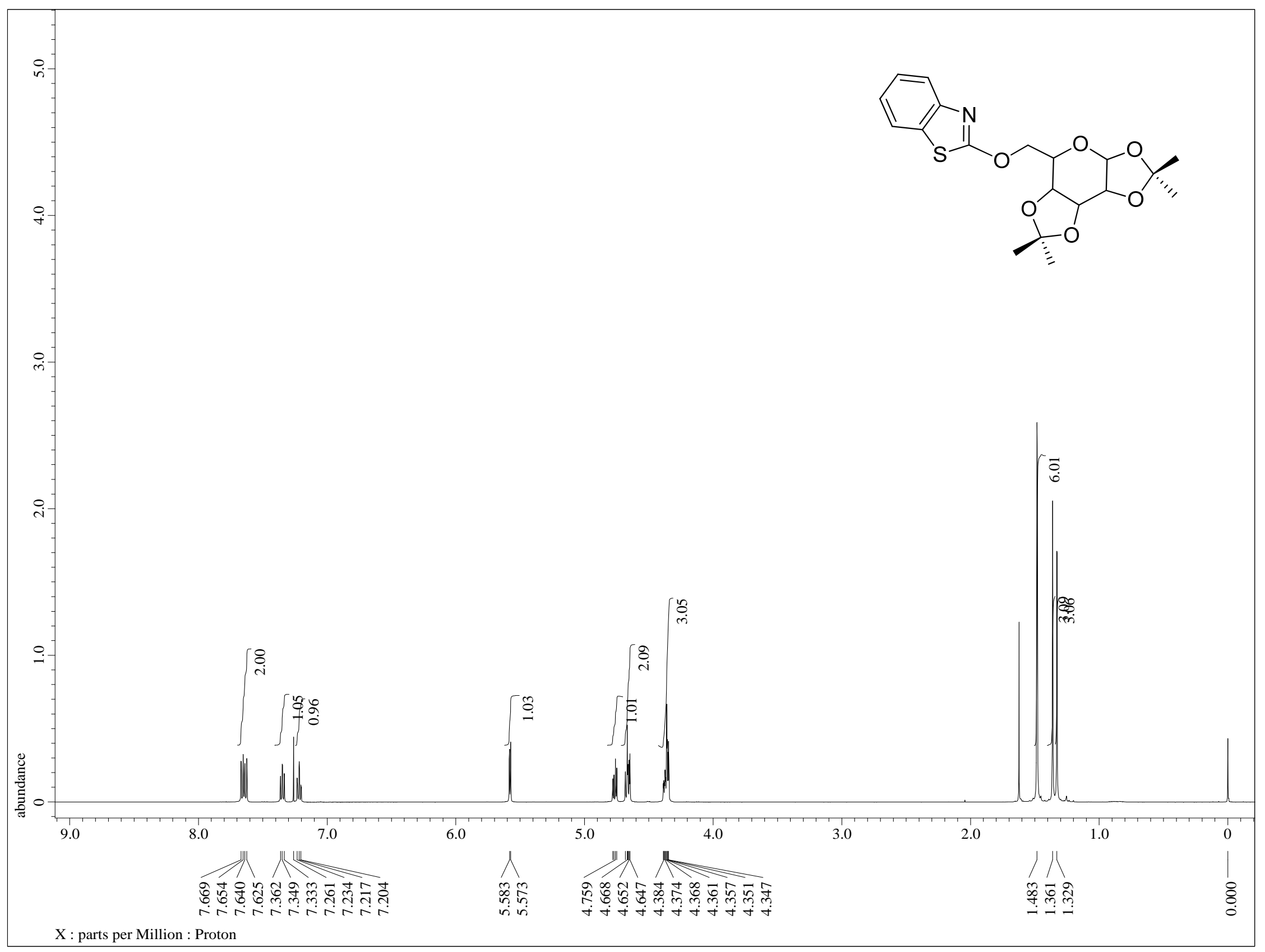

Figure S35: ${ }^{1} \mathrm{H}$ NMR $\left(500 \mathrm{MHz}, \mathrm{CDCl}_{3}\right)$ of compound $2 \mathbf{r}$ 


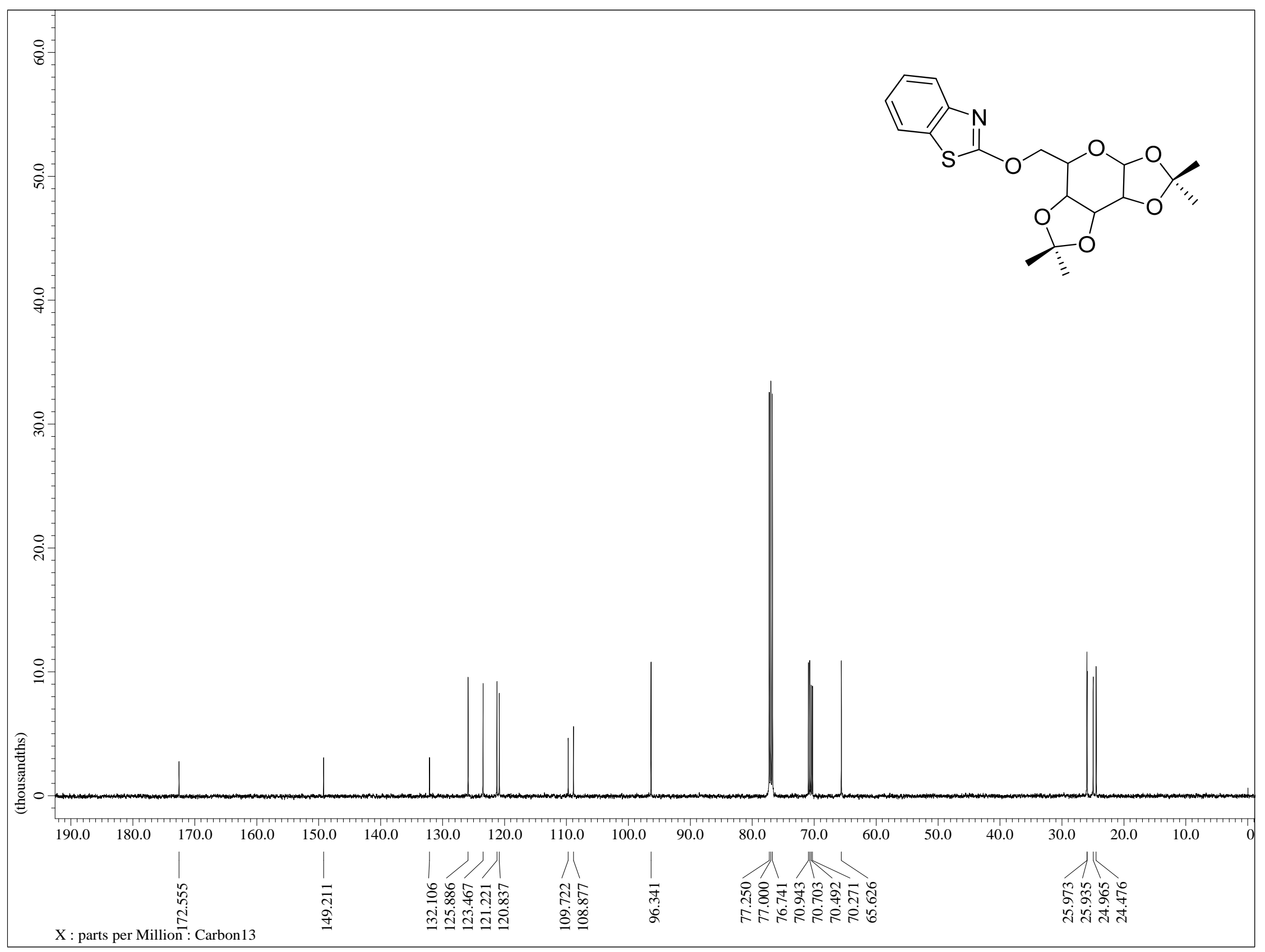

Figure S36: ${ }^{13} \mathrm{C}$ NMR $\left(125 \mathrm{MHz}, \mathrm{CDCl}_{3}\right)$ of compound $2 \mathbf{r}$ 


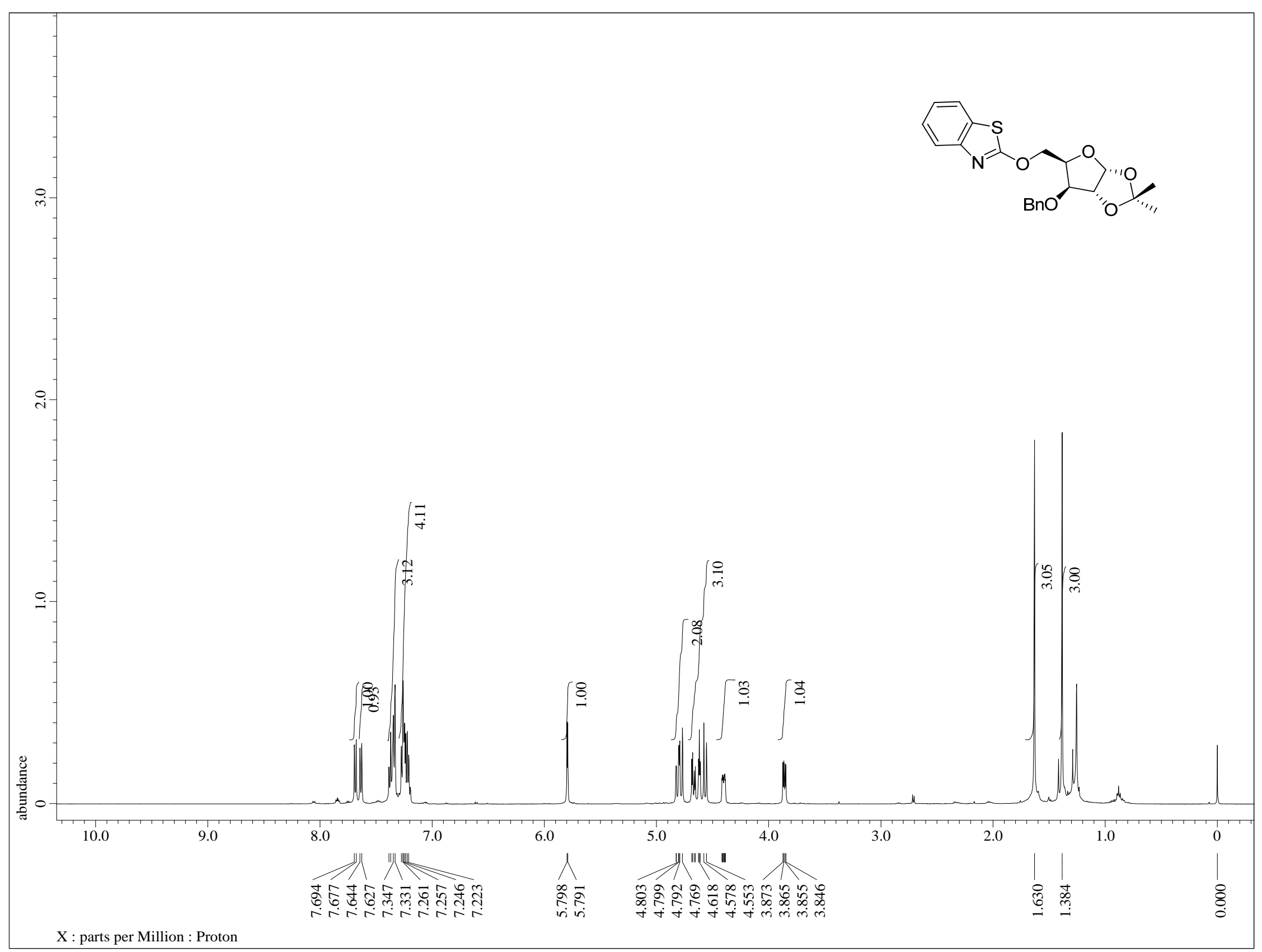

Figure S37: ${ }^{1} \mathrm{H} \mathrm{NMR}\left(500 \mathrm{MHz}, \mathrm{CDCl}_{3}\right)$ of compound 2s 


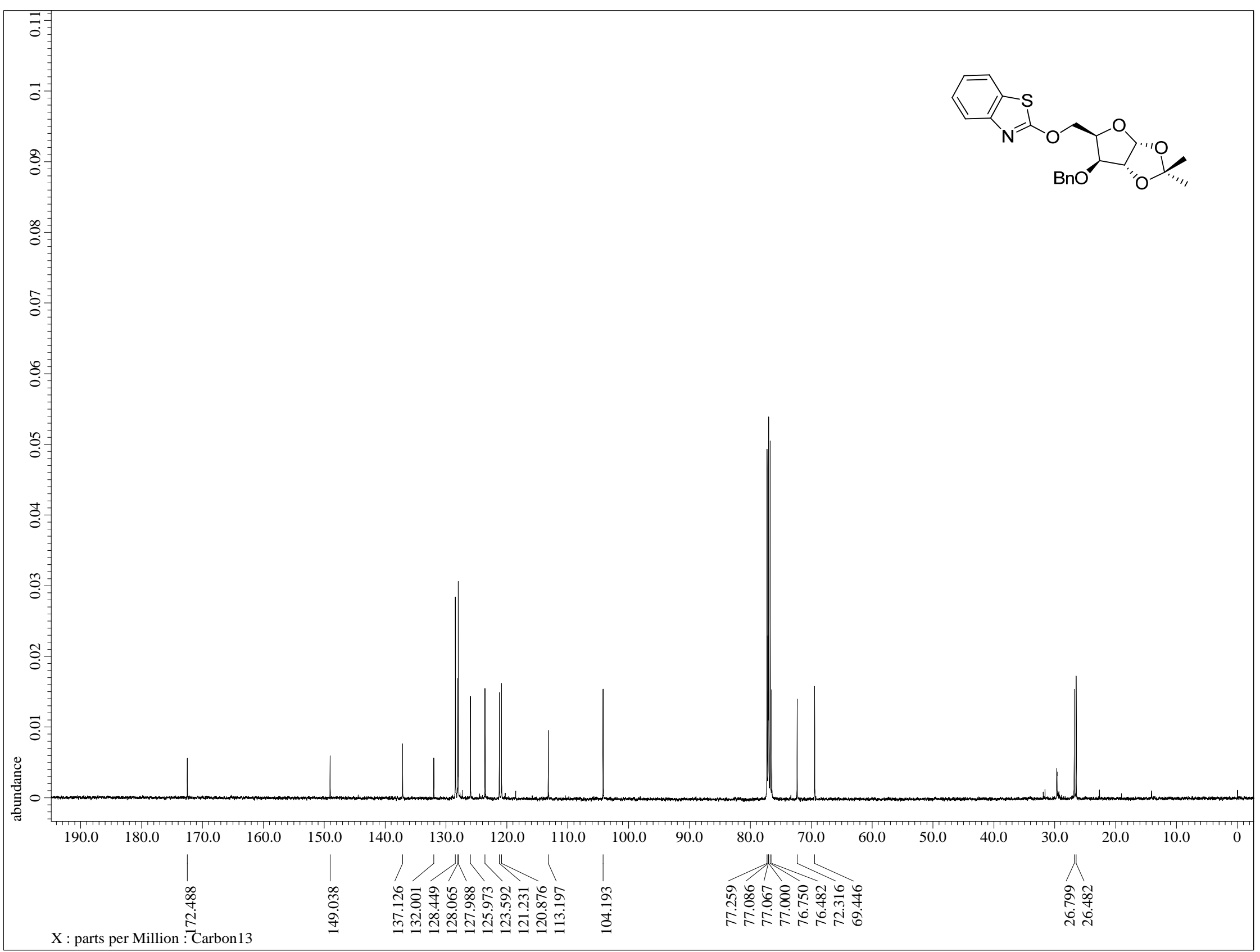

Figure S 38: ${ }^{13} \mathrm{C}$ NMR $\left(125 \mathrm{MHz}, \mathrm{CDCl}_{3}\right.$ ) of compound 2s 


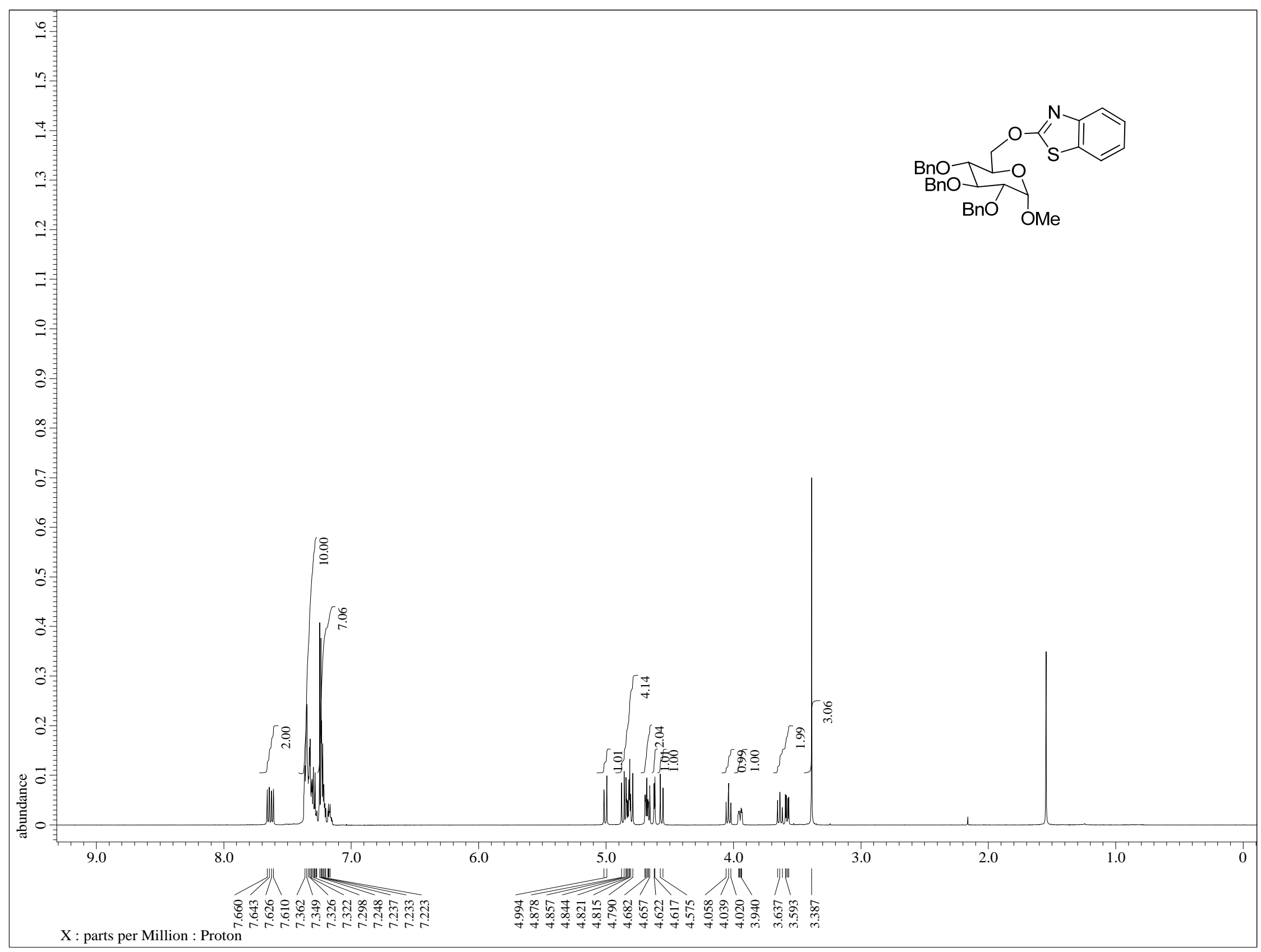

Figure S 39: ${ }^{1} \mathrm{H}$ NMR (500 MHz, $\left.\mathrm{CDCl}_{3}\right)$ of compound 2t 


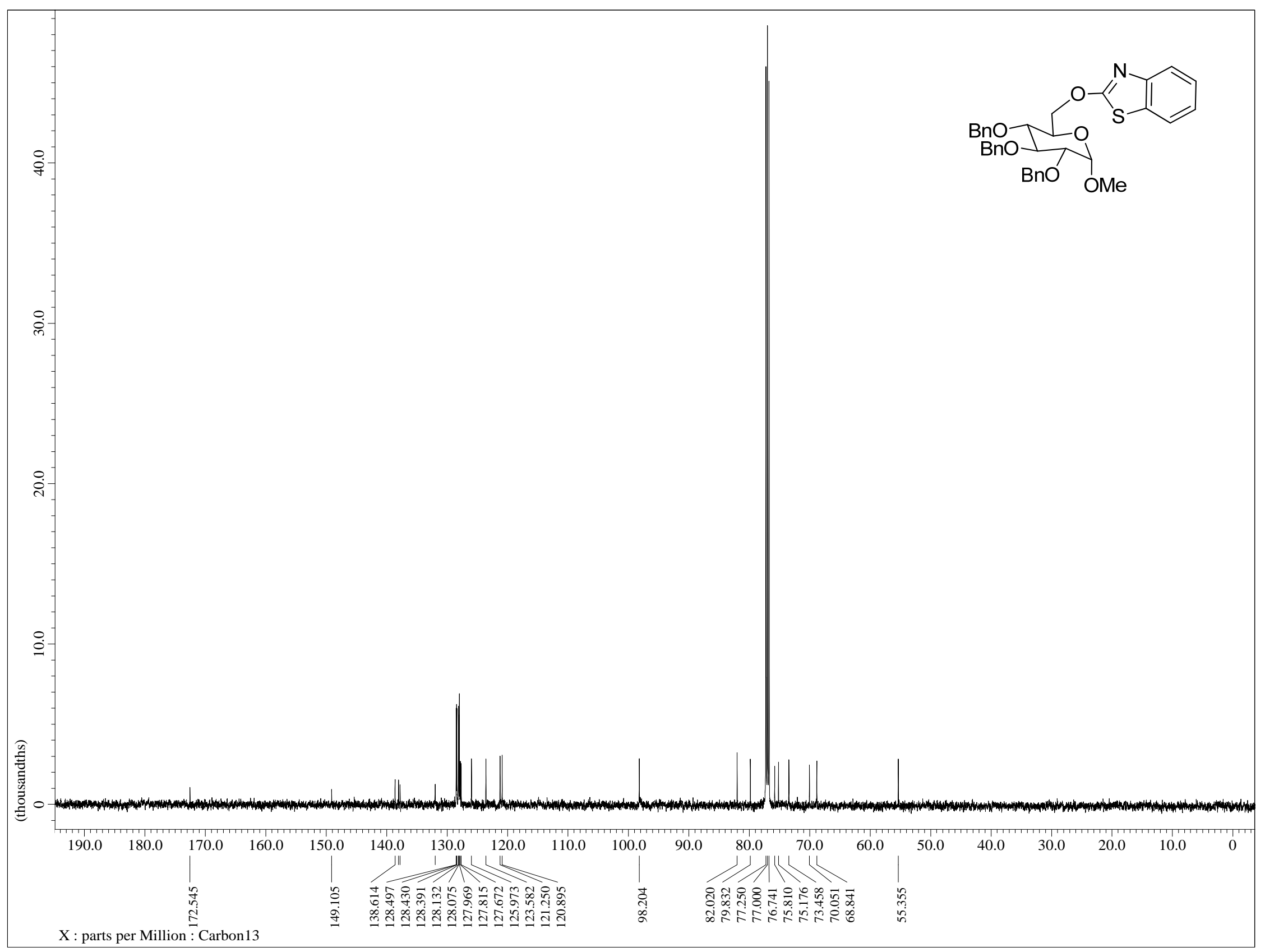

Figure S 40: ${ }^{13} \mathrm{C}$ NMR (125 MHz, $\mathrm{CDCl}_{3}$ ) of compound 2t 


\section{Reference:}

1. Kumar, D.; Mishra, B. B.; Tiwari, V. K. Synthesis of 2-N/S/C-Substituted Benzothiazoles via Intramolecular Cyclative Cleavage of Benzotriazole Ring. J. Org. Chem. 2014, 79, 251-266.

2. Hess, A.; Sehnert, J.; Weyhermu1ller. T.; Metzler-Nolte, N. Chiral ferrocene amines derived from amino acids and peptides: synthesis, solution and X-ray crystal structures and electrochemical investigations. Inorg. Chem. 2000, 39, 5437-5443.

3. Kumar, D.; Mishra, A.; Mishra, B. B.; Bhattacharya, S.; Tiwari, V. K. Synthesis of Glycoconjugate Benzothiazoles via Cleavage of Benzotriazole Ring. J. Org. Chem. 2013, 78, 899-909. 